\title{
On the Factors Influencing Consumers' Adoption of Social Commerce - A Review of the Empirical Literature
}

\author{
Thomas Friedrich \\ Chair of Industrial Information Systems \\ University of Bamberg \\ Bamberg, Germany \\ thomas.friedrich@uni-bamberg.de
}

\begin{abstract}
Social commerce, the combination of e-commerce activities and social media, is a lucrative means for e-commerce companies to increase their sales volumes. As social commerce initiatives considerably depend on the consumers' social interactions, it becomes important for companies to understand how consumers can be stimulated to participate in social commerce. While several empirical studies have already focused on investigating what factors influence consumers to adopt to social commerce, the findings of these studies are scattered across the literature base, sometimes not transparent, and not straightforwardly comparable. To synthesize these findings, we conduct a systematic review of the empirical literature on the consumers' adoption of social commerce. In particular, we identify and classify conceptually similar factors and outcome variables (i.e., behavioral intentions and/or behaviors). Moreover, we apply a votecounting technique and a sign test to aggregate the reported effects between the factors and outcome variables. After analyzing 61 academic publications, we contribute a structured and comprehensive list of factors and their potential effects on various adoption-related outcome variables. Our results reveal that for some factors, such as trust, usefulness, or social influence, the effects point in a clear direction, while for several other factors, such as enjoyment, risk, or social presence, the effects are yet not clear and require further investigations.
\end{abstract}

Keywords: Social commerce, adoption, consumer behavior, literature review, vote counting 


\section{Introduction}

Social commerce is considered as a form of electronic commerce (e-commerce) that combines commercial activities and social media in order to enable consumers to actively participate, interact, and communicate in the online selling and buying of products and services (Wang and Zhang, 2012; Zhou et al., 2013). On social commerce platforms, consumers can not only purchase products but also share their shopping experiences, get advice from trusted peers, or collaborate online to custom-design products or to receive price discounts (Curty and Zhang, 2013; Huang and Benyoucef, 2013). Promoting the consumers' social interactions and relationships, which are formed through the use of social media, is a key characteristic of social commerce and can significantly influence the consumers' purchase behavior (Liang et al., 2011). Consequently, many ecommerce companies today are highly interested in figuring out how they can effectively deploy social commerce to increase their sales volumes (Stephen and Toubia, 2010; Zhou et al., 2013). As social commerce initiatives considerably depend on the consumers' social interactions, it becomes important for companies to understand how consumers can be stimulated to participate in social commerce (Turban et al., 2010; Zhang and Benyoucef, 2016).

While research on social commerce is still at an early stage (Baethge et al., 2016; Zhang and Benyoucef, 2016), several empirical studies have already explored what factors influence consumers to adopt to social commerce. However, understanding the results of these studies is difficult due to the following reasons. First, some of the examined factors, such as trust, have been conceptualized in different ways. For instance, trust in company (Shi and Chow, 2015), trust towards community (Chen and Shen, 2015), or trust in website (Hsiao et al., 2010). Second, different outcome variables (i.e., behavioral intentions and/or behaviors) have been used to measure the consumers' adoption of social commerce, such as consumers' purchase intention/behavior (Lu et al., 2016; Pöyry et al., 2013), continuance intention/behavior (Hajli et al., 2015; Liang et al., 2011), or information sharing intention/behavior (Chen and Shen, 2015; Liu et al., 2016b). Third, different effects have been identified between the same factors and outcome variables, such as trust might or might not significantly influence the consumers' purchase intention (Farivar et al., 2016; Hsiao et al., 2010).

As a result, the current social commerce literature does not provide a clear understanding of the factors that influence consumers to adopt to social commerce. Therefore, researchers investigating this topic first have to synthesize the fragmented and often inconclusive findings in the literature. Considering the current number of social commerce publications (cf. section 3), this task can easily become cumbersome and time-consuming, however. Moreover, there is a risk that existing concepts are overlooked and reinvented, which would make the understanding of social commerce adoption even more complicated. While there already exist a few literature reviews on social commerce, most of these studies either focus on the concept of social commerce or its historical evolution and not on the consumers' adoption of social commerce (Baethge et al., 2016; Busalim and Hussin, 2016; Zhou et al., 2013). So far, only Zhang and Benyoucef (2016) review the literature on the consumer behavior in social commerce and present a framework that integrates various factors and outcome variables. However, the framework does not provide information about the different conceptualizations of the factors and their potential effects on the outcome variables. In the present paper, we consequently aim to synthesize the different conceptions in the social commerce literature and contribute to a better understanding of the factors influencing the consumers' adoption 
of social commerce. We address the following research questions:

1. What factors and outcome variables have been investigated in the literature on social commerce adoption?

2. What effects exist between the identified factors and outcome variables?

To answer these questions, we systematically review the literature on social commerce adoption. In so doing, we contribute to the social commerce literature by synthesizing past research to provide a structured and comprehensive list of factors and their potential effects on various adoption-related outcome variables.

The remainder of this paper is organized as follows. First, we briefly explain the concept of social commerce and illustrate the basic theories behind social commerce adoption. Second, we describe our research methodology to systematically review the literature on the consumers' adoption of social commerce. Third, we present the identified factors and their potential effects on various adoption-related outcome variables. In the subsequent section, we discuss the implications and limitations of our work. Finally, we conclude with a brief summary.

\section{Theoretical Background}

In this section, we provide background information on the concept of social commerce and on the basic theories behind social commerce adoption.

\section{Concept of Social Commerce}

Historically, the roots of social commerce can be traced back to the late 1990s (Curty and Zhang, 2011; Wang and Zhang, 2012). At this time, e-commerce pioneers, such as Amazon and eBay, introduced features on their websites that enabled consumers to write product reviews or to rate the performance of sellers (Saundage and Lee, 2011). With the emergence of web 2.0 and social media, e-commerce companies started to integrate new technologies into their websites to provide consumers a more social and interactive shopping experience (Curty and Zhang, 2013; Ickler et al., 2009). In 2005, Yahoo! first used the term social commerce to describe a new collaborative shopping feature on its shopping platform that allowed consumers to create, share, and comment on product lists (Wang and Zhang, 2012). In 2007, first academic publications appeared that explicitly referred to the concept of social commerce (e.g., Leitner and Grechenig, 2007a; Leitner and Grechenig, 2007b).

With its characteristic combination of economic, social, and technological aspects, social commerce has drawn attention from different research disciplines such as information systems, marketing, or sociology (Wang and Zhang, 2012; Zhou et al., 2013). As a result, current literature provides a variety of social commerce definitions, which makes it difficult to derive a clear understanding of the concept. For instance, Dennison et al. (2009, p. 2) describe social commerce as "the concept of word-of-mouth, applied to e-commerce". According to Stephen and Toubia (2010, p. 215), social commerce connects individual consumers as sellers and represents a form of "Internet-based social media that allow people to participate actively in the marketing and selling of products and services in online marketplaces and communities". Liang and Turban $(2011$, p. 6) define social commerce as "a subset of ecommerce that involves using social media to assist in e-commerce transactions and activities". In a broader sense, Wang and Zhang (2012, p. 106) describe social commerce as "a form of commerce that is mediated by social media and is converging both online and offline environments".

Different understandings also exist of what can be considered as a social commerce website. According to the literature, two major types of social commerce websites can be identified: (1) social networking sites that incorporate commercial features (e.g., product catalogs, shopping carts, or 
payment services); and (2) traditional ecommerce websites that add social mediabased features (e.g., discussion forums, rating and review tools, or share and like buttons) to facilitate consumers' social interactions and exchanges (Curty and Zhang, 2011; Liang and Turban, 2011).

When comparing social commerce and ecommerce, social commerce is considered as a subset or evolution of e-commerce that enhances the consumers' shopping experience by promoting social interactions and relationships, while traditional ecommerce focuses on maximizing the efficiency of transactional processes (Liang and Turban, 2011; Wang and Zhang, 2012). Conceptually similar to social commerce are the terms "social shopping", "collaborative shopping", and "collaborative commerce". In literature, all three terms have been used synonymously to refer to the concept of social commerce or have been considered as a subset of social commerce (Olbrich and Holsing, 2011; Wang and Zhang, 2012; Zhou et al., 2013).

In this study, we adopt the definition of Liang and Turban (2011) and consider social commerce as a form of e-commerce that involves using social media to support e-commerce transactions and activities. In so doing, we intend to obtain a holistic view of the consumers' adoption of social commerce as this definition is not limited to a specific set of consumer activities (e.g., purchasing, marketing, or selling activities) or to a specific type of social commerce websites (e.g., social networking websites, e-commerce websites).

\section{Basic Theories behind Social Commerce Adoption}

As social commerce is closely related to ecommerce, basic theories used to explain ecommerce adoption have also been applied in the context of consumers' adoption of social commerce (Liang et al., 2011; Wang and Zhang, 2012). Referring to the ecommerce literature, an individual consumer's adoption of e-commerce can be defined as "the consumer's engagement in online exchange relationships with Web vendors" (Pavlou and Fygenson, 2006, pp. 115-116). To examine the consumers' adoption of e-commerce, behavioral theories such as the Theory of Reasoned Action (TRA), the Theory of Planned Behavior (TPB), or the Technology Acceptance Model (TAM) have been often used as lenses for analysis (Gefen et al., 2003; Grandón et al., 2011; Koufaris, 2002; Pavlou and Fygenson, 2006). In general, all three theories posit that an individual's behavior can be predicted by his or her intention towards the behavior. However, different factors are suggested by these theories to determine the individual's behavioral intention. In the TRA, the behavioral intention depends on an individual's attitude and on the subjective norms concerning the behavior (Fishbein and Ajzen, 1975). As an extension of the TRA, the TPB uses the factor perceived behavioral control besides subjective norms and attitude to determine the behavioral intention (Ajzen, 1985). In the TAM, which is grounded on the TRA, perceived ease of use and perceived usefulness are used to explain a user's attitude and behavioral intention towards using a certain technology (Davis, 1989). In the e-commerce literature, much effort has been spent to adapt these theories to the specific characteristics of ecommerce. As a result, various research models have been developed and a wide range of different factors has been identified that influence the consumers' intentions and/or behaviors on e-commerce websites (Cheung et al., 2005).

By drawing on the TRA, TPB, and TAM, we use the term "adoption" in this study to refer to the different behavioral intentions and/or behaviors of consumers on social commerce websites. In line with the literature, we also use the term "outcome variables" in this study to refer to the consumers' behavioral intentions and/or behaviors as theses variables have typically been employed as outcome measures in studies focusing on the consumers' adoption of social commerce (Bai et al., 
2015; Liang et al., 2011; Wang and Yu, 2015).

\section{Research Methodology}

To analyze the literature on the consumers' adoption of social commerce, we conducted a systematic literature review. Following the guidelines of Webster and Watson (2002), our literature review consisted of two steps: (1) identifying the relevant literature; and (2) structuring the review. In the following subsections, we describe how we performed these steps.

\section{Identifying the Relevant Literature}

We started with specifying our literature search process. In general, a literature search comprises the querying of scholarly databases and conducting backward and/or forward searches (Webster and Watson, 2002). For the literature search, we adopted the procedure of Zhou et al. (2013), who conducted a bibliometric study on the concept of social commerce. To search for potentially relevant publications, we used the following databases: ACM Digital Library, AIS Electronic Library, EBSCOhost Business Source Complete, IEEE Xplore, ScienceDirect, SpringerLink, and Thomson Reuters Web of Science. In so doing, our literature search covered a broad range of academic publications, including highquality IS journals and conference proceedings. We did not limit our search to a specific set of journals because we wanted to obtain a complete and up-to-date picture of the social commerce literature. Following Zhou et al. (2013), we searched these databases using keywords such as "social commerce", "social shopping", "collaborative commerce", and "collaborative shopping". By using these keywords, we concentrated our search on publications that explicitly refer to the concept of social commerce or to conceptually similar forms of social commerce (cf. section 2). We did not search for the keyword "adoption" because not all publications focusing on social commerce adoption use this term. As search fields, we used title, abstract, and keywords where applicable. Considering that first research on social commerce emerged in 2007 (Wang and Zhang, 2012; Zhou et al., 2013), we searched for literature published between January 2007 and September 2016. To ensure a certain quality level, we only considered peer-reviewed academic publications (including journal articles, conference papers, and book chapters). Reports, whitepapers, and other types of literature were excluded. In addition, we only focused on publications written in English.

By following the above-described procedure, we identified 767 articles referring to the concept of social commerce. After removing duplicate entries, we obtained 491 unique articles. We then screened these articles on their relevance to our research questions. The screening based on examining the title, abstract, and, if necessary, the full text of each article. Consequently, articles that investigate the effects of one or more factors on the consumers' intentions and/or behaviors on social commerce websites were classified as relevant. Furthermore, relevant articles must provide empirical evidence about the effects of the identified factors. Conceptual studies and research-inprogress papers were excluded. Moreover, we excluded duplicate articles of authors who reported similar results by using the same data sets. In this way, we reduced the list of relevant articles to 53. As recommended by Webster and Watson (2002), we performed backward and forward searches on these articles. By doing so, we additionally identified 8 relevant articles. Finally, a total set of 61 relevant articles remained for further analysis and classification. The set consisted of 42 journal articles, 17 conference papers, and 2 book chapters. The articles were published between the years 2010 and 2016. 


\section{Structuring the Review}

To synthesize our results, we followed the recommendations of Webster and Watson (2002) to use a concept-centric approach. In general, concepts determine the structuring framework of a review (Webster and Watson, 2002). In our review, the concepts are represented by the factors and outcome variables that have been investigated in the relevant literature on social commerce adoption. For this purpose, we read each article carefully and compiled a list of all examined factors, outcome variables, and the reported effects between factors and outcome variables (i.e., significant negative, non-significant, and significant positive effects). Note that only factors were added to the list, which have been assumed in the literature to have a direct effect on the outcome variables. For instance, Kim and Park (2013) examine how various seller and website characteristics (e.g., reputation, size, transaction safety, communication, etc.) influence the consumers' trust and how trust influences the consumers' purchase and word-of-mouth intentions. Accordingly, we added the factor "trust" and the two outcome variables (i.e., "purchase intentions", "word-of-mouth intentions") to our list but not the various seller and website characteristics of social commerce. To further synthesize the results, we grouped conceptually similar factors together by examining their definitions and measurement items. For instance, all trustrelated factors such as "trust", "trustworthiness", "trust in members", and "trust in company" were grouped under the factor "trust". Conceptually different factors that had only been examined in one article were grouped under "others". In the same way, we grouped the outcome variables. For instance, "intention to purchase products", "intention to buy", and "purchase behavior" were grouped under the outcome variable "purchase intention/behavior". To highlight the importance of the factors, we sorted the list in descending order beginning with the factor that had been examined in most of the articles. The result of this procedure was a structured and comprehensive list of factors and their potential effects on various adoption-related outcome variables (cf. Appendix A).

To condense the results of the factors that had been examined in more than one article, we counted all similar effects (i.e., significant negative effects, non-significant effects, significant positive effects) between the factors and outcome variables. For instance, Liang et al. (2011) and Hajli et al. (2015) report a significant positive effect of social support on the consumers' continuance intention/behavior. Accordingly, we counted two positive effects of the factor "social support" on the outcome variable "continuance intention/behavior". Studies reporting multiple effects of one factor were counted individually. For instance, Kwahk and $\mathrm{Ge}$ (2012) report a significant positive effect of informational social influence and a significant negative effect of normative social influence on the consumers' purchase intention. Consequently, we counted one positive and one negative effect of the factor "social influence" on the outcome variable "purchase intention/behavior". Counting the number of similar effects corresponds to the votecounting method developed by Light and Smith (1971). In general, vote counting is considered as a simple meta-analysis technique in which the number of significant positive, significant negative and nonsignificant findings is compared and the category with the largest number is used to determine the direction of a focal relationship (Cooper, 1998). However, vote counting has some inherent limitations (Hedges and Olkin, 1980; King and He, 2005). For instance, it does not take into account differences in the sample sizes, effect sizes, or the applied data analysis approaches. The presented numbers of significant positive, significant negative, and non-significant effects should therefore be interpreted with caution. We applied vote counting in our review because it enabled us to provide a quantitative summary of the reported effects and to detect causal 
relationships that require further empirical investigations. Moreover, we considered vote counting as appropriate because research on social commerce is still at an early stage and not all of the relevant articles provide information about the sample size, effect size, or the applied data analysis approach. To overcome some of the shortcomings of vote counting, we followed the recommendations of Cooper (1998) and combined the vote-counting results with a sign test.

\section{Results}

Figure 1 presents the concept-centric classification of the identified factors and outcome variables. Overall, we identified 16 factors, which were examined in more than one study. These factors are: trust, usefulness, enjoyment, social influence, social support, value, ease of use, relationship quality, attitude, risk, commitment, social commerce constructs, familiarity, satisfaction, social presence, and uncertainty. Moreover, we identified 6 outcome variables which have been used in the relevant studies to measure the consumers' adoption of social commerce. These variables are: use intention/behavior, purchase intention/behavior, continuance intention/behavior, information sharing intention/behavior, information seeking intention/behavior, and information disclosure intention/behavior. In the following subsections, we will first provide information on the outcome variables and then describe the frequently examined factors (i.e., factors examined in more than one study) and their effects on the outcome variables. We focus on the frequently examined factors to find out if these factors have been conceptualized in different ways and if there exist differences in the reported effects of these factors. The full list of all identified factors, including the factors that have only been examined in one study, and their effects can be found in Appendix A.

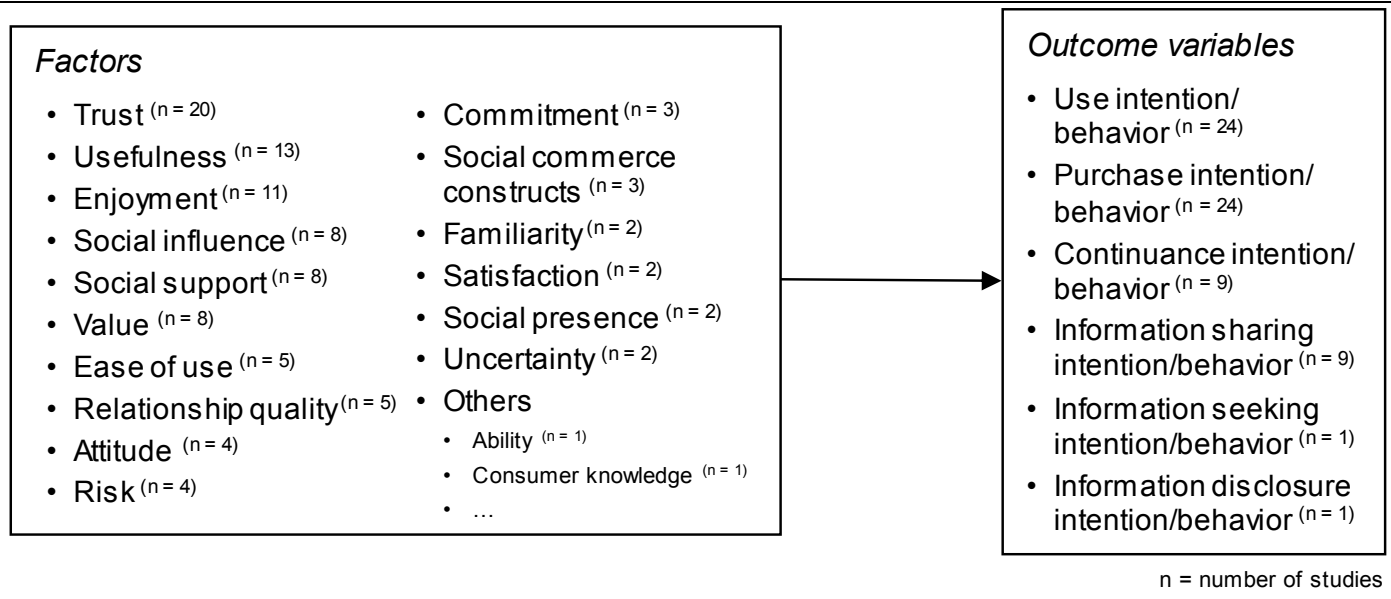

Figure 1 - Classification of Factors and Outcome Variables

\section{Findings on the Outcome Variables}

Table 1 describes the identified outcome variables. As illustrated in Figure 1, 24 studies focus on the consumers' use intention/behavior, which addresses the general use of a social commerce website. In these studies, the variable use intention/behavior or a conceptually similar variable is used to refer to a combination of social commerce activities that consumers can do on a social commerce website. For instance, Shen (2012a), Shin (2013), and Teh and Ahmed (2011) consider it as using a social commerce website to discover new products, to purchase products, and to recommend products to other consumers. In 
a similar way, Liang et al. (2011), Hajli and Sims (2015), and Zhang et al. (2014) use the variable social commerce intention/behavior to refer to activities such as purchasing products recommended by other consumers, and considering, receiving, and sharing of shopping information. Farivar et al. (2016), Kang and Johnson (2015), and Zhang et al. (2015) use the variable participation intention/behavior to refer to similar activities.

The variable purchase intention/behavior, which is also investigated in 24 studies, refers to the purchasing of products and/or services on a social commerce website. Examples of studies using this variable are: Anderson et al. (2014), Hajli (2014a), Hsiao et al. (2010), Liu et al. (2016a), and $\mathrm{Ng}$ (2013). Moreover, some studies use the variable impulsive buying intention/behavior in this context to focus on the spontaneous and unplanned purchases of consumers on social commerce websites (Huang, 2016; Song et al., 2015; Xi et al., 2016; Xiang et al., 2016).

9 studies examine the variable continuance intention/behavior, which addresses the continuous use of a social commerce website, including activities such as revisiting a social commerce website and repurchasing products and/or services from a social commerce website (Hajli et al., 2015; Jang et al., 2013; Kim et al., 2013b; Liang et al., 2011). In a similar way, some researchers use the variable loyalty to measure whether a consumer is interested in continuously using a social commerce website (Anderson et al., 2014; Chen et al., 2014; Gamboa and Gonçalves, 2014; Lee et al., 2012; Zhang et al., 2016).

To investigate the consumers' willingness to share shopping information with other consumers on a social commerce website, 9 studies employ the variable information sharing intention/behavior (Chen and Shen, 2015; Cheung et al., 2015; Liu et al., 2013; Liu et al., 2016b; Liu et al., 2014). In this context, some studies also conceptualize this variable as electronic word-of-mouth (eWOM) intention/behavior (Chen et al., 2014; Hudson et al., 2015; Kim and Park, 2013; Shi and Chow, 2015).

Finally, 1 study examines the consumers' intention/behavior to seek shopping information provided by other consumers on a social commerce website (Qin and Kong, 2015), and 1 study examines the consumers' intention/behavior to disclosure personal information on a social commerce website (Sharma and Crossler, 2014a).

\begin{tabular}{|c|c|}
\hline Outcome variable & Definition \\
\hline Use intention/behavior & $\begin{array}{l}\text { Consumers' intention or behavior to use a social commerce website. Refers to a } \\
\text { combination of various social commerce activities, such as purchasing products } \\
\text { recommended by other consumers, and considering, receiving, and sharing of shopping } \\
\text { information. Also conceptualized as social commerce intention/behavior or participation } \\
\text { intention/behavior. }\end{array}$ \\
\hline $\begin{array}{l}\text { Purchase } \\
\text { intention/behavior }\end{array}$ & $\begin{array}{l}\text { Consumers' intention or behavior to purchase products (planned or impulsively) on a } \\
\text { social commerce website. }\end{array}$ \\
\hline $\begin{array}{l}\text { Continuance } \\
\text { intention/behavior }\end{array}$ & $\begin{array}{l}\text { Consumers' intention or behavior to continuously use a social commerce website (e.g., } \\
\text { revisiting the website, repurchasing products, or recommending products to other } \\
\text { consumers). Also conceptualized as loyalty. }\end{array}$ \\
\hline $\begin{array}{l}\text { Information sharing } \\
\text { intention/behavior }\end{array}$ & $\begin{array}{l}\text { Consumers' intention or behavior to share shopping information with other consumers } \\
\text { on a social commerce website. Also conceptualized as electronic word-of-mouth } \\
\text { (eWOM) intention/behavior. }\end{array}$ \\
\hline $\begin{array}{l}\text { Information seeking } \\
\text { intention/behavior }\end{array}$ & $\begin{array}{l}\text { Consumers' intention or behavior to seek shopping information on a social commerce } \\
\text { website. }\end{array}$ \\
\hline $\begin{array}{l}\text { Information disclosure } \\
\text { intention/behavior }\end{array}$ & $\begin{array}{l}\text { Consumers' intention or behavior to disclosure information on a social commerce } \\
\text { website. }\end{array}$ \\
\hline
\end{tabular}

8 Pacific Asia Journal of the Association for Information Systems Vol. 8 No. 4, pp.1-32 / December 2016 https://aisel.aisnet.org/pajais/vol8/iss4/2 


\section{Findings on the Factors and their Effects}

Table 2 lists the frequently examined factors together with their effects on the outcome variables. The factors are ordered descending by the number of studies ( $n$ ). The effects are counted by applying the vote-counting technique (cf. section 3 ) and are classified into the groups significant negative effect $(p<0.05)$, non-significant effect, and significant positive effect $(p<0.05)$. For each factor, we provide a summary of the effects per outcome variable (SPV, summary per outcome variable) and a summary of the effects per factor (SPF, summary per factor). The former is used to illustrate the percentage of studies that confirm an assumed effect between the factor and outcome variable. The latter is used to illustrate the factors overall confirmed effects on the outcome variables. In addition, we provide a short definition for each factor and we illustrate how the factor has been conceptualized by listing the names of its constructs.

According to our results, the factor trust has received the most attention in the literature on social commerce adoption $(n=20)$. In the relevant studies, various forms of trust have been investigated. For instance, Chen and Shen (2015) and Ng (2013) demonstrate that the consumers' trust in the community of a social commerce website can significantly increase the consumers' use and purchase intention/behavior. Moreover, Farivar et al. (2016) and Qin and Kong (2015) report that the consumers' trust in the social commerce website can significantly increase the consumers' use, purchase, and information seeking intention/behavior. Other studies present a significant positive effect of the consumers' trust in the seller or the company behind the social commerce website on the consumers' use, purchase, and information sharing intention/behavior (Lu et al., 2016; Ruan et al., 2016; Shi and Chow, 2015). Unclear is the importance of the consumers' trust towards the members of a social commerce site. Farivar et al. (2016) report a non- significant effect of this variable on the consumers' use and purchase intention/behavior, while Chen and Shen (2015) report a significant positive effect on the purchase intention/behavior and a nonsignificant effect on the information sharing intention/behavior. Other studies focus on conceptually similar forms of trust but without redefining the construct (Gamboa and Gonçalves, 2014; Hajli, 2012; Hajli and Sims, 2015; Liu et al., 2013; Shen, 2012b; Teh and Ahmed, 2012; Zhang et al., 2015). Overall, our findings indicate that the factor trust plays an important role in the consumers' adoption of social commerce (26/32 effects are significantly positive). Trust has been reported to significantly increase the consumers use (8/10), purchase (10/11), continuance (2/2), information sharing $(5 / 7)$, and information seeking (1/1) intention/behavior.

Derived from the TAM (cf. section 2), the factor usefulness is examined in 13 studies. 12 studies (e.g., Featherman and Hajli, 2015; Hajli, 2012; Kim, 2015; Noh et al., 2013; Shen, 2012a) define the variable as usefulness or perceived usefulness and 1 study (Gatautis and Medziausiene, 2014) uses the conceptually similar variable performance expectancy, which is part of the Unified Theory of Acceptance and Use of Technology (UTAUT) (Venkatesh et al., 2003). In these studies, usefulness has been confirmed to influence the use $(7 / 8)$, purchase $(3 / 3)$, and information disclosure $(1 / 1)$ intention/behavior. Not clear is the effect of usefulness on the information sharing intention/behavior (0/1). Overall, the importance of usefulness is represented by $11 / 13$ studies reporting a significant positive effect on the outcome variables. Besides usefulness, the factor enjoyment has been investigated in 11 studies. In these studies, enjoyment has been measured by employing constructs such as perceived enjoyment or flow, which have been operationalized with similar items (e.g., Liu et al., 2016a; Shen, 2012a; Shin, 2013; Zhang et al., 2014). In context of information sharing, Liu et al. (2014) and Liu et al. 
(2016b) investigate the consumers' enjoyment of helping other consumers and report a significant positive and a nonsignificant effect (1/2). In addition, enjoyment has significant positive effects on the use (5/6), purchase (2/3), and information disclosure (1/1) intention/behavior. Overall, $9 / 12$ of the reported effects confirm a significant positive effect of enjoyment on the outcome variables. The findings on the factors usefulness and enjoyment underpin the argumentation of Wang and Zhang (2012) that social commerce combines utilitarian and hedonic aspects.

Two factors that are related to the consumers' social interactions and relationships are social influence and social support. Both factors have been examined in 8 studies. Different forms of social influence have been investigated such as normative social influence (also conceptualized as subjective norm or normative belief) and informational social influence (e.g., Featherman and Hajli, 2015; Gatautis and Medziausiene, 2014; Kwahk and Ge, 2012; Shin, 2013; Xi et al., 2016). Derived from the TRA (cf. section 2) and the UTAUT, social influence has been confirmed to have significant positive effects on the use (7/7), purchase (3/4), and continuance intention (1/1). Interestingly, Kwahk and Ge (2012) detect a negative effect of normative social influence on the purchase intention/behavior. Overall, 11/12 of the reported effects confirm a significant positive effect of social influence on the outcome variables. Clear effects have been associated with the factor social support (9/9 significant positive effects). Studies confirm that social support positively influences the consumers use (5/5), purchase (2/2), and continuance (2/2) intention (e.g., Bai et al., 2015; Hajli, 2014b; Li et al., 2014; Liang et al., 2011; Shin, 2013; Zhang et al., 2014).

Another factor that has been investigated in 8 studies is value, which stems from the marketing literature (Zeithaml, 1988). In the social commerce literature, different forms of value have been examined, such as perceived value, utilitarian value, hedonic value, informational value, and social value (e.g., Gamboa and Gonçalves, 2014; Hu et al., 2016; Kim et al., 2013a; Ruan et al., 2016; Sun et al., 2016). According to the literature, value has been reported to have positive effects on the use (4/5), purchase (6/7), and continuance (3/4) intention/behavior. Overall, 13/16 effects are significantly positive.

5 studies examine the factor ease of use, which is part of the TAM. To measure ease of use, 4 studies (Featherman and Hajli, 2015; Hajli and Lin, 2015; Noh et al., 2013; Teh and Ahmed, 2012) use the variable perceived usefulness and 1 study (Gatautis and Medziausiene, 2014) employs the conceptually similar variable effort expectancy, which is suggested by the UTAUT. According to these studies, ease of use has a significant positive effect on the use (3/4) and the purchase (1/1) intention/behavior. However, Teh and Ahmed (2012) report a non-significant effect of ease of use on the use intention/behavior. Derived from the marketing literature, the factor relationship quality is typically considered as a combination of trust, commitment, and satisfaction (HennigThurau et al., 2002). Referring to our results, 5 studies examine this factor (Hajli, 2014b; Hudson et al., 2015; Liang et al., 2011; Wang and Hajli, 2014; Zhang et al., 2016). According to these studies, relationship quality positively influences the consumers' use (3/3), continuance (2/2), and information sharing (1/1) intention/behavior. All reported effects of relationship quality on the outcome variables are significantly positive (6/6).

According to the TRA and the TPB (cf. section 2), attitude is an important factor that influences an individual's behavioral intention. In the context of social commerce adoption, 4 studies demonstrate that the consumers' attitude towards social commerce has significant positive effects on the use (2/3) and continuance (1/1) intention/behavior. However, Teh and 
Ahmed (2011) examine a non-significant effect of attitude on the purchase intention/behavior. Given the distant and impersonal nature of the online environment, risk is considered as an inevitable element of e-commerce (Pavlou, 2003). Referring to the social commerce literature, risk has been examined in 4 studies. In these studies, various forms of risk have been investigated such as perceived risk (Ruan et al., 2016), perceived privacy risk (Sharma and Crossler, 2014a), assessed usage risk (Featherman and Hajli, 2015), perceived participation risk (Farivar et al., 2016), and perceived commerce risk (Farivar et al., 2016). Ruan et al. (2016) report a nonsignificant effect of risk on the use intention/behavior, while Featherman and Hajli (2015) and Farivar et al. (2016) detect significant negative effects (2/3). In addition, Farivar et al. (2016) report a significant negative effect of risk on the purchase (1/1) intention/behavior and Sharma and Crossler (2014a) report a significant negative effect of risk on the information disclosure (1/1) intention/behavior. Overall, 4/5 effects are significantly negative.

Rooted in relationship marketing, commitment is considered as a crucial factor that drives the persistence of social relationships (Morgan and Shelby, 1994). According to our results, 3 studies report significant positive effects of commitment on the use (2/2) and the continuance (2/2) intention/behavior (Chen and Shen, 2015; Gamboa and Gonçalves, 2014; Zhang et al., 2015). Some attention has also been given to the social features and/or social platforms that enable social commerce, such as, ratings and reviews, recommendations and referrals, or forums and communities. Conceptualized as social commerce constructs, 3 studies report significant positive effects of this variable on the use $(2 / 2)$ and the purchase (1/1) intention/behavior (Hajli, 2015; Hajli and Sims, 2015; Wang and Hajli, 2014).

Factors that have been examined in 2 studies are familiarity, satisfaction, social presence, and uncertainty. Referring to familiarity, 1 study (Sharma and Crossler, 2014b) provides evidence that familiarity positively influences the consumers' use intention/behavior (1/1), and 1 study $(\mathrm{Ng}$, 2013) reports a non-significant effect of familiarity on the purchase intention/behavior (0/1). Also derived from marketing literature, the factor satisfaction has been confirmed to positively affect the consumers' continuance

intention/behavior (Gamboa and Gonçalves, 2014; Jang et al., 2013). In these studies, different forms of satisfaction have been investigated such as customer satisfaction (Gamboa and Gonçalves, 2014) or site/coupon satisfaction (Jang et al., 2013). To facilitate consumers' social interactions, social commerce platforms provide features that enable consumers to create their own identities and to present themselves (Huang and Benyoucef, 2013). In this context, 2 studies have assumed that the factor social presence positively influences the consumers' use intention (Sharma and Crossler, 2014b; Zhang et al., 2014). However, Zhang et al. (2014), who investigated two different social commerce websites, reported a significantly positive effect and a non-significant effect of social presence on the use intention/behavior. In addition, Sharma and Crossler (2014b) also report a non-significant effect of social presence on the use intention/behavior. According to these findings, it seems not clear if social presence has a significant impact on the consumers' adoption of social commerce $(1 / 3$ of the effects are significant positive). However, findings in the literature indicate that social presence can influence the consumers' intentions/behaviors on social commerce websites through other factors, such as trust, enjoyment, or perceived usefulness (Hwang et al., 2014; Kim, 2015; Shen, 2012a; Zhang et al., 2014). Similar to risk, the factor uncertainty negatively affects the outcome variables. Bai et al. (2015) and Hwang et al. (2014) report $3 / 3$ significant negative effects of uncertainty on the purchase intention/behavior. 


\section{Table 2 - Frequently Examined Factors and their Effects}

Trust ( $\mathbf{n}=\mathbf{2 0}$ )

Definition

The confidence a person has in his or her favorable expectations of what another party (e.g., person or company) will do, based, in many cases, on previous interactions (Gefen, 2000). Willingness to be vulnerable to another party based on beliefs in ability, benevolence, and integrity (Gefen et al., 2003; McKnight et al., 2002; Pavlou, 2003).

\begin{tabular}{|c|c|c|c|c|c|c|}
\hline Constructs & \multicolumn{6}{|c|}{$\begin{array}{l}\text { Trust, perceived trust, perceived trustworthiness of SNSs, trust in social network community, trus } \\
\text { towards community, trust towards members, trust in vendor, company trust, trust in sellers, trust } \\
\text { towards website, trust in website, trust in product recommendation, information-based trust, } \\
\text { identification-based trust }\end{array}$} \\
\hline \multirow{7}{*}{$\begin{array}{l}\text { Influence } \\
\text { on ... }\end{array}$} & \multirow{2}{*}{ Outcome variable } & \multicolumn{3}{|c|}{ Effect (vote-count) } & \multirow{2}{*}{ SPV } & \multirow{2}{*}{ SPF } \\
\hline & & - & 0 & + & & \\
\hline & Use intention/behavior & & 2 & 8 & $80 \%(8 / 10)$ & \multirow{5}{*}{$\begin{array}{l}81 \% \\
(26 / 32)\end{array}$} \\
\hline & Purchase intention/behavior & & 1 & 10 & $91 \%(10 / 11)$ & \\
\hline & Continuance intention/behavior & & & 2 & $100 \%(2 / 2)$ & \\
\hline & Information sharing intention/behavior & & 2 & 5 & $71 \%(5 / 7)$ & \\
\hline & Information seeking intention/behavior & & 1 & 1 & $50 \%(1 / 2)$ & \\
\hline \multicolumn{7}{|c|}{ Usefulness $(n=13)$} \\
\hline Definition & \multirow{2}{*}{\multicolumn{6}{|c|}{$\begin{array}{l}\text { The degree to which a person believes that using a particular s } \\
\text { enhances his or her performance (Davis, 1989). } \\
\text { Usefulness, perceived usefulness, performance expectancy }\end{array}$}} \\
\hline Constructs & & & & & & \\
\hline \multirow{6}{*}{$\begin{array}{l}\text { Influence } \\
\text { on ... }\end{array}$} & \multirow{2}{*}{ Outcome variable } & Ef & vot & unt) & \multirow{2}{*}{ SPV } & \multirow{2}{*}{ SPF } \\
\hline & & - & 0 & + & & \\
\hline & Use intention/behavior & & 1 & 7 & $88 \%(7 / 8)$ & \multirow{4}{*}{$\begin{array}{l}85 \% \\
(11 / 13)\end{array}$} \\
\hline & Purchase intention/behavior & & & 3 & $100 \%(3 / 3)$ & \\
\hline & Information sharing intention/behavior & & 1 & & $0 \%(0 / 1)$ & \\
\hline & Information disclosure intention/behavior & & & 1 & $100 \%(1 / 1)$ & \\
\hline
\end{tabular}

\section{Enjoyment $(\mathbf{n}=11)$}

\begin{tabular}{|c|c|c|c|c|c|c|}
\hline Definition & \multicolumn{6}{|c|}{$\begin{array}{l}\text { The extent to which the activity of using a particular system (e.g., commercial website) is perceived } \\
\text { to be enjoyable (Davis et al., 1992). Conceptually similar to flow (Koufaris, 2002), which refers to } \\
\text { the holistic sensation that people feel when they act with total involvement (Csikszentmihalyi and } \\
\text { Csikszentmihalyi, 1988). }\end{array}$} \\
\hline Constructs & \multicolumn{6}{|c|}{$\begin{array}{l}\text { Enjoyment, perceived enjoyment, enjoyment of helping, enjoyment in helping others, flow, flow } \\
\text { experience }\end{array}$} \\
\hline \multirow{6}{*}{$\begin{array}{l}\text { Influence } \\
\text { on ... }\end{array}$} & \multirow{2}{*}{ Outcome variable } & \multicolumn{3}{|c|}{ Effect (vote-count) } & \multirow{2}{*}{ SPV } & \multirow{2}{*}{ SPF } \\
\hline & & - & $\mathbf{0}$ & + & & \\
\hline & Use intention/behavior & & 1 & 5 & $83 \%(5 / 6)$ & \multirow{4}{*}{$\begin{array}{l}75 \% \\
(9 / 12)\end{array}$} \\
\hline & Purchase intention/behavior & & 1 & 2 & $67 \%(2 / 3)$ & \\
\hline & Information sharing intention/behavior & & 1 & 1 & $50 \%(1 / 2)$ & \\
\hline & Information disclosure intention/behavior & & & 1 & $100 \%(1 / 1)$ & \\
\hline \multicolumn{7}{|c|}{ Social influence $(n=8)$} \\
\hline Definition & \multicolumn{6}{|c|}{$\begin{array}{l}\text { The pressure that an individual perceives from significant others to perform, or not to perform, a } \\
\text { certain behavior (Deutsch and Gerard, 1955; Rivis and Sheeran, 2003). }\end{array}$} \\
\hline Constructs & \multicolumn{6}{|c|}{$\begin{array}{l}\text { Social influence, normative social influence, informational social influence, subjective norm, } \\
\text { normative belief }\end{array}$} \\
\hline \multirow{5}{*}{$\begin{array}{l}\text { Influence } \\
\text { on ... }\end{array}$} & \multirow{2}{*}{ Outcome variable } & \multicolumn{3}{|c|}{ Effect (vote-count) } & 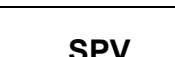 & \multirow{2}{*}{ SPF } \\
\hline & & - & 0 & + & SPV & \\
\hline & Use intention/behavior & & & 7 & $100 \%(7 / 7)$ & \multirow{3}{*}{$\begin{array}{l}92 \% \\
(11 / 12)\end{array}$} \\
\hline & Purchase intention/behavior & 1 & & 3 & $75 \%(3 / 4)$ & \\
\hline & Continuance intention/behavior & & & 1 & $100 \%(1 / 1)$ & \\
\hline
\end{tabular}




\begin{tabular}{|c|c|c|c|c|c|c|}
\hline \multicolumn{7}{|c|}{ Social support $(n=8)$} \\
\hline Definition & \multicolumn{6}{|c|}{$\begin{array}{l}\text { The degree to which an individual perceives that he or she is of being cared for, being responded } \\
\text { to, and being helped by people in that individual's social network (Cobb, 1976; Lakey and Cohen, } \\
\text { 2000). }\end{array}$} \\
\hline Constructs & \multicolumn{6}{|c|}{ Social support } \\
\hline \multirow{5}{*}{$\begin{array}{l}\text { Influence } \\
\text { on } \ldots\end{array}$} & \multirow{2}{*}{ Outcome variable } & \multicolumn{3}{|c|}{ Effect (vote-count) } & \multirow{2}{*}{ SPV } & \multirow{2}{*}{ SPF } \\
\hline & & - & $\mathbf{0}$ & + & & \\
\hline & Use intention/behavior & & & 5 & $100 \%(5 / 5)$ & \multirow{3}{*}{$\begin{array}{l}100 \% \\
(9 / 9)\end{array}$} \\
\hline & Purchase intention/behavior & & & 2 & $100 \%(2 / 2)$ & \\
\hline & Continuance intention/behavior & & & 2 & $100 \%(2 / 2)$ & \\
\hline \multicolumn{7}{|c|}{ Value $(n=8)$} \\
\hline Definition & \multirow{2}{*}{\multicolumn{6}{|c|}{$\begin{array}{l}\text { The consumer's overall assessment of the utility of a product (or service), based on perceptions of } \\
\text { what is received and what is given (Zeithaml, 1988). } \\
\text { Perceived value, utilitarian value, perceived utilitarian value, product utilitarian value, social value, } \\
\text { perceived social value, hedonic value, shopping hedonic value, self-discovery value, informational } \\
\text { value }\end{array}$}} \\
\hline Constructs & & & & & & \\
\hline \multirow{5}{*}{$\begin{array}{l}\text { Influence } \\
\text { on ... }\end{array}$} & \multirow{2}{*}{ Outcome variable } & \multicolumn{3}{|c|}{ Effect (vote-count) } & & \multirow{2}{*}{ SPF } \\
\hline & & - & 0 & + & SPV & \\
\hline & Use intention/behavior & & 1 & 4 & $80 \%(4 / 5)$ & \multirow{3}{*}{$\begin{array}{l}81 \% \\
(13 / 16)\end{array}$} \\
\hline & Purchase intention/behavior & & 1 & 6 & $86 \%(6 / 7)$ & \\
\hline & Continuance intention/behavior & & 1 & 3 & $75 \%(3 / 4)$ & \\
\hline \multicolumn{7}{|c|}{ Ease of use $(n=5)$} \\
\hline Definition & \multicolumn{6}{|l|}{$\begin{array}{l}\text { The degree to which a person believes tha } \\
\text { would be free of effort (Davis, 1989). }\end{array}$} \\
\hline Constructs & \multicolumn{6}{|l|}{ Perceived ease of use, effort expectancy } \\
\hline \multirow{4}{*}{$\begin{array}{l}\text { Influence } \\
\text { on ... }\end{array}$} & \multirow{2}{*}{ Outcome variable } & \multicolumn{3}{|c|}{ Effect (vote-count) } & SDY $>$ & \multirow{2}{*}{ SPF } \\
\hline & & - & 0 & + & SPV & \\
\hline & Use intention/behavior & & 1 & 3 & $75 \%(3 / 4)$ & \multirow{2}{*}{$\begin{array}{l}80 \% \\
(4 / 5) \\
\end{array}$} \\
\hline & Purchase intention/behavior & & & 1 & $100 \%(1 / 1)$ & \\
\hline \multicolumn{7}{|c|}{ Relationship quality $(n=5)$} \\
\hline Definition & \multirow{2}{*}{\multicolumn{6}{|c|}{$\begin{array}{l}\text { The overall strength of the relationship betweer } \\
\text { et al., 1990). Typically considered as a higher-c } \\
\text { commitment, and satisfaction (Hennig-Thurau } \epsilon \\
\text { Relationship quality, brand relationship quality }\end{array}$}} \\
\hline Constructs & & & & & & \\
\hline Influence & & & vote & Int) & & \\
\hline on ... & Outcome variable & - & 0 & + & SPV & SPF \\
\hline & Use intention/behavior & & & 3 & $100 \%(3 / 3)$ & $100 \%$ \\
\hline & Continuance intention/behavior & & & 2 & $100 \%(2 / 2)$ & $(6 / 6)$ \\
\hline & Information sharing intention/behavior & & & 1 & $100 \%(1 / 1)$ & \\
\hline Attitude (n & =4) & & & & & \\
\hline Definition & $\begin{array}{l}\text { The degree to which a person has a fa } \\
\text { (Ajzen, 1985; Fishbein and Ajzen, } 197\end{array}$ & unfe & & ration & ff the behavic & n question \\
\hline Constructs & Attitude, attitude towards s-commerce & & & & & \\
\hline & Outcome variablo & Eff & vote & int) & & \\
\hline on ... & Uutcome variadie & - & 0 & + & SPV & SPF \\
\hline & Use intention/behavior & & 1 & 2 & $67 \%(2 / 3)$ & $75 \%$ \\
\hline & Continuance intention/behavior & & & 1 & $100 \%(1 / 1)$ & $(3 / 4)$ \\
\hline Risk (n = 4 & & & & & & \\
\hline Definition & $\begin{array}{l}\text { The consumers' subjective assessmer } \\
\text { (e.g., a purchase) might produce (Bett }\end{array}$ & ; Co & & & s that a cer & behavior \\
\hline
\end{tabular}




\begin{tabular}{|c|c|c|c|c|c|c|}
\hline \multirow{6}{*}{$\begin{array}{l}\text { Constructs } \\
\text { Influence } \\
\text { on ... }\end{array}$} & \multicolumn{6}{|c|}{$\begin{array}{l}\text { Perceived risk, perceived privacy risk, perceived commerce risk, assessed usage risk, perceived } \\
\text { participation risk }\end{array}$} \\
\hline & \multirow{2}{*}{ Outcome variable } & \multicolumn{3}{|c|}{ Effect (vote-count) } & \multirow{2}{*}{ SPV } & \multirow{2}{*}{ SPF } \\
\hline & & - & 0 & + & & \\
\hline & Use intention/behavior & 2 & 1 & & $67 \%(2 / 3)$ & \multirow{3}{*}{$\begin{array}{l}80 \% \\
(4 / 5)\end{array}$} \\
\hline & Purchase intention/behavior & 1 & & & $100 \%(1 / 1)$ & \\
\hline & Information disclosure intention/behavior & 1 & & & $100 \%(1 / 1)$ & \\
\hline \multicolumn{7}{|c|}{ Commitment $(n=3)$} \\
\hline Definition & \multicolumn{6}{|c|}{ The consumer's desire to maintain a valued relationship (Morgan and Shelby, 1994). } \\
\hline Constructs & \multicolumn{6}{|c|}{ Commitment, community commitment } \\
\hline \multirow{4}{*}{$\begin{array}{l}\text { Influence } \\
\text { on ... }\end{array}$} & \multirow{2}{*}{ Outcome variable } & \multicolumn{3}{|c|}{ Effect (vote-count) } & \multirow{2}{*}{ SPV } & \multirow{2}{*}{ SPF } \\
\hline & & - & 0 & + & & \\
\hline & Use intention/behavior & & & 2 & $100 \%(2 / 2)$ & \multirow{2}{*}{$\begin{array}{l}100 \% \\
(4 / 4)\end{array}$} \\
\hline & Continuance intention/behavior & & & 2 & $100 \%(2 / 2)$ & \\
\hline \multicolumn{7}{|c|}{ Social commerce constructs $(n=3)$} \\
\hline Definition & \multicolumn{6}{|c|}{$\begin{array}{l}\text { Refers to the social features and/or social platforms that enable social commerce (Hajli, 2015). } \\
\text { Typically conceptualized as a higher-order construct that is composed of the factors ratings and } \\
\text { reviews, recommendations and referrals, and forums and communities (Hajli, 2012; Hajli, 2015; } \\
\text { Hajli and Sims, 2015). }\end{array}$} \\
\hline Constructs & \multicolumn{6}{|l|}{ Social commerce constructs } \\
\hline \multirow{4}{*}{$\begin{array}{l}\text { Influence } \\
\text { on ... }\end{array}$} & \multirow{2}{*}{ Outcome variable } & \multicolumn{3}{|c|}{ Effect (vote-count) } & \multirow{2}{*}{ SPV } & \multirow{2}{*}{ SPF } \\
\hline & & - & 0 & + & & \\
\hline & Use intention/behavior & & & 2 & $100 \%(2 / 2)$ & \multirow{2}{*}{$\begin{array}{l}100 \% \\
(3 / 3) \\
\end{array}$} \\
\hline & Purchase intention/behavior & & & 1 & $100 \%(1 / 1)$ & \\
\hline Familiarity & $n=2)$ & & & & & \\
\hline Definition & $\begin{array}{l}\text { The knowledge that people have of a pro } \\
\text { previous contacts (Luhmann, 1979). Also } \\
\text { shopping website (Gefen, 2000). }\end{array}$ & & & $\begin{array}{l}\text { sis of } \\
\text { Imer's }\end{array}$ & $\begin{array}{l}\text { eir experienc } \\
\text { understanding }\end{array}$ & and \\
\hline Constructs & Familiarity & & & & & \\
\hline Influence & & & vote & unt) & & \\
\hline on ... & Outcome variable & - & 0 & + & SPV & SPF \\
\hline & Use intention/behavior & & & 1 & $100 \%(1 / 1)$ & $50 \%$ \\
\hline & Purchase intention/behavior & & 1 & & $0 \%(0 / 1)$ & $(1 / 2)$ \\
\hline Satisfactio & $(n=2)$ & & & & & \\
\hline Definition & $\begin{array}{l}\text { The consumer's overall emotional evalua } \\
\text { provider (Gustafsson et al., 2005). }\end{array}$ & & & ith a & rtain product & rvice \\
\hline Constructs & Customer satisfaction, coupon satisfactio & atis & & & & \\
\hline Influence & Outrome variable & & vote & unt) & SPY & SPF \\
\hline on ... & Uutcome variadole & - & 0 & + & SPV & SPr \\
\hline & Continuance intention/behavior & & & 4 & $100 \%(4 / 4)$ & $100 \%(4 / 4)$ \\
\hline Social pres & ence $(n=2)$ & & & & & \\
\hline Definition & $\begin{array}{l}\text { The degree to which a medium permits us } \\
\text { et al., 1987; Short et al., 1976). }\end{array}$ & & & as $p$ & chologically & esent (Fulk \\
\hline Constructs & Social presence & & & & & \\
\hline Influence & Outcome variahle & & vote & unt) & SPY $>>2>$ & SPF \\
\hline on ... & Outcome variable & - & 0 & + & SPV & SPF \\
\hline & Use intention/behavior & & 2 & 1 & $33 \%(1 / 3)$ & $33 \%(1 / 3)$ \\
\hline Uncertaint & $(n=2)$ & & & & & \\
\hline Definition & $\begin{array}{l}\text { The degree to which the future states of } t \\
\text { be accurately anticipated or predicted by } \\
2007) \text {. }\end{array}$ & & & $\begin{array}{l}\text { outc } \\
\text { rfect }\end{array}$ & $\begin{array}{l}\text { ne of a transa } \\
\text { formation }(\mathrm{Pa}\end{array}$ & $\begin{array}{l}\text { tion) cannot } \\
\text { ou et al., }\end{array}$ \\
\hline
\end{tabular}

14 Pacific Asia Journal of the Association for Information Systems Vol. 8 No. 4, pp.1-32 / December 2016 https://aisel.aisnet.org/pajais/vol8/iss4/2 


\begin{tabular}{|l|l|c|c|c|c|c|}
\hline Constructs & Uncertainty, product uncertainty, seller uncertainty & \multicolumn{2}{|c|}{ SPV } & \multirow{2}{*}{ SPF } \\
\cline { 1 - 4 } $\begin{array}{l}\text { Influence } \\
\text { on ... }\end{array}$ & Outcome variable & - & $\mathbf{0}$ & $\mathbf{+}$ & & \\
\cline { 2 - 7 } & Purchase intention/behavior & 3 & & & $100 \%(3 / 3)$ & $100 \%(3 / 3)$ \\
\hline
\end{tabular}

Notes: $\mathrm{n}=$ number of studies. $-=$ significant negative effect $(\mathrm{p}<0.05) ; 0=$ non-significant effect; $+=$ significant positive effect $(p>0.05)$. SPV $=$ summary per variable. SPF $=$ summary per factor.

Finally, Table 3 presents the results of the sign test. We use the sign test to verify whether the reported effects per factor indicate that one direction occurs more frequently than chance would suggest. It helps us to reveal the relative strengths of the effects by comparing the number of positive findings and the overall number of findings. We performed the sign test as recommended by Cooper (1998). For each factor, a z score (i.e., standard normal deviate) is calculated by using the formula of Cooper (1998, p. 118). The formula is illustrated in Appendix B. Significance levels (i.e. two-tailed p-values) are calculated on the $z$ scores. As the results of the sign test demonstrate, the factor trust can clearly be considered as an important factor in the consumers' adoption of social commerce as the direction of the reported effects is highly significant $(p<0.001)$. Both social influence and social support can also be considered to play a significant role in the consumers' adoption of social commerce (direction of effects is significant at $\mathrm{p}<0.01)$. Other factors for which the direction of effects is confirmed as statistically significant are usefulness, value, relationship quality, commitment, and satisfaction $(p<0.05)$. Factors for which the direction of the effects are not confirmed to be statistically significant are enjoyment, ease of use, attitude, risk, social commerce constructs, familiarity, social presence, and uncertainty. Note that the results of the sign test should be interpreted with caution due to the low number of studies behind most of the factors. This means that the results can change when a new study confirms or disconfirms one or more effects.

\section{Table 3 - Results of Sign Test}

\begin{tabular}{|l|l|l|l|l|c|}
\multirow{2}{*}{ Factor } & \multicolumn{2}{|c|}{$\mathbf{N}$} & \multicolumn{3}{c|}{ Sign test } \\
\cline { 2 - 6 } & \multicolumn{1}{|c|}{ Positive } & \multicolumn{1}{|c|}{ Total } & \multicolumn{1}{c|}{ Z score } & Sig. value & Sig. level \\
\hline Trust & 26 & 32 & 3.5355 & 0.000407 & ${ }^{* * *}$ \\
\hline Usefulness & 11 & 13 & 2.4962 & 0.012553 & ${ }^{*}$ \\
\hline Enjoyment & 9 & 12 & 1.7321 & 0.083256 & n.s. \\
\hline Social influence & 11 & 12 & 2,8868 & 0.003892 & ${ }^{* *}$ \\
\hline Social support & 9 & 9 & 3,0000 & 0.002700 & ${ }^{* *}$ \\
\hline Value & 13 & 16 & 2,5000 & 0.012419 & ${ }^{*}$ \\
\hline Ease of use & 4 & 5 & 1,3416 & 0.179726 & n.s. \\
\hline Relationship quality & 6 & 6 & 2,4495 & 0.014305 & ${ }^{*}$ \\
\hline Attitude & 3 & 4 & 1,0000 & 0.317311 & n.s. \\
\hline Risk & 4 & 5 & 1,3416 & 0.179726 & n.s. \\
\hline Commitment & 4 & 4 & 2,0000 & 0.045500 & ${ }^{*}$ \\
\hline Social commerce constructs & 3 & 3 & 1,7321 & 0.083256 & n.s. \\
\hline Familiarity & 1 & 2 & 0,0000 & 1.000000 & n.s. \\
\hline Satisfaction & 4 & 4 & 2,0000 & 0.045500 & ${ }^{*}$ \\
\hline Social presence & 1 & 3 & $-0,5774$ & 0.563939 & n.s. \\
\hline Uncertainty & 3 & 3 & 1,7321 & 0.083256 & n.s. \\
\hline Notes: N = number of reported effects. Sig. $=$ significance. ${ }^{*}=p<0.05 ;{ }^{* *}=p<0.01 ;{ }^{* *}=p<0.001 ;$ n.s. $=$
\end{tabular}

not significant. 


\section{Discussion}

In this section, we discuss the implications and limitations of our study.

\section{Theoretical and Practical Implications}

Our results demonstrate that research on the consumers' adoption of social commerce so far has examined a wide range of factors and outcome variables. With respect to the identified outcome variables, different behavioral intentions and/or behaviors have been used in the literature to measure the consumers' adoption of social commerce. However, when examining the consumers' activities in social commerce (Liang and Turban, 2011), there is still room for research to explore additional intentions and/or behaviors. For instance, researchers could examine the consumers' intention/behavior to collaborate on social commerce websites or to help and support other consumers (Ickler et al., 2009; Rad and Benyoucef, 2010; Saundage and Lee, 2011). Furthermore, we did not identify any outcome variables that address the consumers' intention/behavior to sell products on social commerce websites, which is considered as a part of social commerce (Stephen and Toubia, 2010; Wang and Zhang, 2012). Researchers should be careful when adopting and redefining outcome variables. As our results reveal, several studies define the outcome variables in a different way (e.g., use, participation, or social commerce intention/behavior) but measure these variables with identical items. Researchers should also be careful when grouping different social commerce activities (e.g. requesting and sharing of shopping information) into one variable as these activities might be affected in different ways. Instead, we suggest to separately measure the different consumer intentions/behaviors, such as demonstrated by Farivar et al. (2016), Hsiao et al. (2010), or Horng et al. (2016). In this way, researchers can not only more precisely examine the different consumer intentions/behaviors but also explore the causal relationships between these intentions/behaviors in order to develop a more complete understanding of the consumers' adoption of social commerce.

Referring to the identified factors and their effects, our results show that the effects of some frequently examined factors, such as trust, usefulness, social influence, or social support, point in a clear direction, while the effects of several other frequently examined factors, such as enjoyment, ease of use, risk, or social presence, are yet not clear and require further investigations. Moreover, many factors have only been examined in one study (see Appendix A), which makes it difficult to assess their importance. Consequently, further investigations on these factors are necessary. Besides, researchers should be careful when defining their own factors. In order to facilitate the comparison of the reported results, researchers should refer to established conceptualizations or clearly explain why factors have been conceptualized in different ways. When examining multidimensional constructs, such as trust, researchers should also precisely explain on what dimension(s) they focus, such as trust in the website (Hsiao et al., 2010), trust in the seller (Lu et al., 2016), or trust in the community ( $\mathrm{Ng}, 2013)$. When looking at the frequently examined factors, many effects have not yet been explored, such as the effects of social influence or social support on the information sharing intention/behavior, the effects of usefulness or enjoyment on the continuance intention/behavior, or the effects trust on the information disclosure intention/behavior. Little is also known about the potential effects of the social features that enable social commerce. While the factor social commerce constructs, as suggested by Hajli (2015), is a first step in this direction, it is still not clear how individual social commerce features influence the consumers' intentions/behaviors. Deriving knowledge about the impacts of these features could support companies to identify and select features that might deliver the 
highest benefits in a particular scenario (Friedrich et al., 2015).

To better understand the consumers' adoption of social commerce, future research could also compare our results with the e-commerce literature and highlight the differences. For instance, factors such as trust, usefulness, ease of use, or risk have also been frequently examined in the e-commerce literature (Gefen et al., 2003; McKnight et al., 2002; Pavlou, 2003; Pavlou and Fygenson, 2006). Therefore, it is important for research to explore the specific characteristics of social commerce.

For practice, our results illustrate that a variety of factors influence consumers to participate in social commerce. Practitioners can use our results as a guideline to determine which factors might drive the success of their social commerce initiatives. For instance, if a company wants to stimulate consumers to return to their social commerce website (i.e., continuance intention/behavior), special attention should be given to factors such as social support, value, or relationship quality (Hajli et al., 2015; Liang et al., 2011).

\section{Limitations}

This study is subject to several limitations. Referring to our literature search, we only concentrated on academic publications that explicitly mentioned the term social commerce or conceptually similar terms such as social shopping, collaborative shopping, or collaborative commerce. Although we conducted backward and forward searches, the use of additional search terms (e.g., "social media" and "buying" or "social media" and "consumer behavior") might have uncovered additional relevant articles. Moreover, we only focused on academic publications written in English. When identifying the relevant literature, we excluded all studies that did not provide empirical evidence about the effects of the factors.

With respect to the identified factors, we only investigated factors that have been assumed in the literature to have a direct effect on the outcome variables. Antecedents of these factors were excluded, such as the various seller and website characteristics (e.g., reputation, size, transaction safety, communication, etc.) investigated by Kim and Park (2013). Furthermore, we only focused on the effects between the factors and the outcome variables and not on the effects between the factors or between the outcome variables. For instance, our results suggest that social presence might not play an important role in the consumers' adoption of social commerce because 2 of 3 studies reported a non-significant effect. However, when looking at the effects reported in the social commerce literature, evidence is given that social presence can influence the consumers' intentions/behaviors through various other factors, such as trust, enjoyment, or perceived usefulness (Hwang et al., 2014; Kim, 2015; Shen, 2012a; Zhang et al., 2014). To derive a complete picture of the consumers' adoption of social commerce, it is thus necessary to also investigate the causal relationships between the factors and between the outcome variables.

To synthesize our results, we grouped conceptually similar factors and outcome variables together by carefully examining their definitions and measurement items. However, there might be other ways to classify these variables. The vote-counting technique, which we used to count the effects between the factors and the outcome variables, does not consider differences in the sample sizes, effect sizes, data analysis approaches, or contexts. To overcome some of these shortcomings, we combined the vote-counting results with a sign test. However, more sophisticated meta-analysis techniques could be applied, especially when a larger set of studies is investigated (King and He, 2005). Another limitation of this study is that it solely focuses on consumers. Considering that businesses are a major part of social commerce (Wang and Zhang, 2012; Zhou 
et al., 2013), it would also be interesting to find out what factors influence companies to adopt to social commerce.

\section{Conclusion}

In this study, we examined the factors that influence the consumers' adoption of social commerce. By conducting a systematic literature review, we summarized and synthesized the results of 61 academic publications on social commerce adoption. In particular, we identified and classified conceptually similar factors and outcome variables (i.e., behavioral intentions and/or behaviors). Moreover, we applied a votecounting technique and a sign test to aggregate the reported effects between the factors and outcome variables. In so doing, we contributed a structured and comprehensive list of factors and their potential effects on various adoption-related outcome variables. Several implications for research and practice were discussed. Main implications for research are: use our list to (1) examine the importance of the factors that have only been examined in one study; (2) verify the consolidated effects of the frequently examined factors and explore new causal relationships; (3) combine the identified factors and outcome variables to develop a more complete understanding of the consumers' adoption of social commerce. By pointing out the limitations of our work, we also highlighted room for future improvements.

The results of our literature review demonstrate that research on social commerce adoption is still at an early stage. To support companies in their social commerce initiatives, it is necessary for research to further explore the factors that drive consumers to participate in social commerce.

\section{References}

Ajzen, I. (1985). "From Intentions to Actions: A Theory of Planned Behavior," in J. Kuhl and J. Beckmann (eds.), Action Control - From Cognition to Behavior. Heidelberg, Germany: Springer, pp. 11-39.

Anderson, K.C., Knight, D.K., Pookulangara, S. and Josiam, B. (2014). "Influence of Hedonic and Utilitarian Motivations on Retailer Loyalty and Purchase Intention: A Facebook Perspective," Journal of Retailing and Consumer Services, 21(5), pp. 773-779.

Baethge, C., Klier, J. and Klier, M. (2016). "Social Commerce - State-of-the-Art and Future Research Directions," Electronic Markets, pp. 1-22.

Bai, Y., Yao, Z. and Dou, Y.-F. (2015). "Effect of Social Commerce Factors on User Purchase Behavior: An Empirical Investigation from Renren.Com," International Journal of Information Management, 35(5), pp. 538-550.

Bettman, J.R. (1973). "Perceived Risk and Its Components: A Model and Empirical Test," Journal of Marketing Research, 10(2), pp. 184-190.

Busalim, A.H. and Hussin, A.R.C. (2016). "Understanding Social Commerce: A Systematic Literature Review and Directions for Further Research," International Journal of Information Management, 36(6), pp. 1075-1088.

Chen, H., Papazafeiropoulou, A., Chen, T.K., Duan, Y. and Liu, H.-W. (2014). "Exploring the Commercial Value of Social Networks," Journal of Enterprise Information Management, 27(5), pp. 576-598.

Chen, J. and Shen, X.-L. (2015). "Consumers' Decisions in Social Commerce Context: An Empirical Investigation," Decision Support Systems, 79, pp. 55-64. 
Cheung, C.M., Chan, G.W. and Limayem, M. (2005). "A Critical Review of Online Consumer Behavior: Empirical Research," Journal of Electronic Commerce in Organizations, 3(4), pp. 1-19.

Cheung, C.M.K., Liu, I.L.B. and Lee, M.K.O. (2015). "How Online Social Interactions Influence Customer Information Contribution Behavior in Online Social Shopping Communities: A Social Learning Theory Perspective," Journal of the Association for Information Science \& Technology, 66(12), pp. 2511-2521.

Cho, Y.-S., Heo, J.-Y. and Youn, M.-K. (2012). "Korean Customer Attitudes Towards SNS Shopping," Journal of Distribution Science, 10(8), pp. 7-14.

Cobb, S. (1976). "Social Support as a Moderator of Life Stress," Psychosomatic Medicine, 38(5), pp. 300-314.

Cooper, H.M. (1998). Synthesizing Research: A Guide for Literature Reviews, (3 ed.). USA: Sage Publications.

Cox, D.F. and Rich, S.U. (1964). "Perceived Risk and Consumer Decision-Making: The Case of Telephone Shopping," Journal of Marketing Research, 1(4), pp. 32-39.

Crosby, L.A., Evans, K.R. and Cowles, D. (1990). "Relationship Quality in Services Selling: An Interpersonal Influence Perspective," The Journal of Marketing, pp. 68-81.

Csikszentmihalyi, M. and Csikszentmihalyi, I.S. (1988). Optimal Experience: Psychological Studies of Flow in Consciousness. Cambridge, United Kingdom: Cambridge University Press.

Curty, R. and Zhang, P. (2011). "Social Commerce: Looking Back and Forward," Proceedings of the American Society for Information Science and Technology, pp. 1-10.
Curty, R. and Zhang, P. (2013). "Website Features that Gave Rise to Social Commerce: A Historical Analysis," Electronic Commerce Research and Applications, 12(4), pp. 260-279.

Davis, F.D. (1989). "Perceived Usefulness, Perceived Ease of Use, and User Acceptance of Information Technology," MIS Quarterly, 13(3), pp. 319-340.

Davis, F.D., Bagozzi, R.P. and Warshaw, P.R. (1992). "Extrinsic and Intrinsic Motivation to Use Computers in the Workplace," Journal of Applied Social Psychology, 22(14), pp. 1111-1132.

Dennison, G., Bourdage-Braun, S. and Chetuparambil, M. (2009). "Social Commerce Defined," IBM, pp. 1-12.

Deutsch, M. and Gerard, H.B. (1955). "A Study of Normative and Informational Social Influences Upon Individual Judgment," The Journal of Abnormal and Social Psychology, 51(3), pp. 629-636.

Farivar, S., Yuan, Y. and Turel, O. (2016). "Understanding Social Commerce Acceptance: The Role of Trust, Perceived Risk, and Benefit," Proceedings of the 22nd Americas Conference on Information Systems (AMCIS), pp. 1-10.

Featherman, M.S. and Hajli, N. (2015). "Self-Service Technologies and eServices Risks in Social Commerce Era," Journal of Business Ethics, 2015, pp. 1-19.

Fishbein, M. and Ajzen, I. (1975). Belief, Attitude, Intention, and Behavior: An Introduction to Theory and Research. Reading, USA: Addison-Wesley.

Friedrich, T., Overhage, S., Schlauderer, S. and Eggs, H. (2015). "Selecting Technologies for Social Commerce: Towards a Systematic Method," Proceedings of the 23rd European Conference on Information Systems (ECIS), pp. 1-17. 
Fulk, J., Steinfield, C.W., Schmitz, J. and Power, J.G. (1987). "A Social Information Processing Model of Media Use in Organizations," Communication Research, 14(5), pp. 529-552.

Gamboa, A.M. and Gonçalves, H.M. (2014). "Customer Loyalty through Social Networks: Lessons from Zara on Facebook," Business Horizons, 57(6), pp. 709-717.

Gatautis, R. and Medziausiene, A. (2014). "Factors Affecting Social Commerce Acceptance in Lithuania," Procedia Social and Behavioral Sciences, 110, pp. 1235-1242.

Gefen, D. (2000). "E-Commerce: The Role of Familiarity and Trust," Omega, 28(6), pp. 725-737.

Gefen, D., Karahanna, E. and Straub, D.W. (2003). "Trust and TAM in Online Shopping: An Integrated Model," MIS Quarterly, 27(1), pp. 51-90.

Grandón, E.E., Nasco, S.A. and Mykytyn, P.P. (2011). "Comparing Theories to Explain E-Commerce Adoption," Journal of Business Research, 64(3), pp. 292-298.

Gustafsson, A., Johnson, M.D. and Roos, I. (2005). "The Effects of Customer Satisfaction, Relationship Commitment Dimensions, and Triggers on Customer Retention," Journal of Marketing, 69(4), pp. 210218.

Hajli, M. (2012). "Social Commerce: The Role of Trust," Proceedings of the 18th Americas Conference on Information Systems (AMCIS), pp. 111.

Hajli, M. (2014a). "A Study of the Impact of Social Media on Consumers," International Journal of Market Research, 56(3), pp. 387-404.

Hajli, M.N. (2014b). "The Role of Social Support on Relationship Quality and
Social Commerce," Technological Forecasting and Social Change, 87, pp. 17-27.

Hajli, N. (2015). "Social Commerce Constructs and Consumer's Intention to Buy," International Journal of Information Management, 35(2), pp. 183-191.

Hajli, N. and Lin, X. (2015). "Consumer Adoption of Social Commerce," Proceedings of the 2nd International Conference on $\mathrm{HCl}$ in Business (HC/B): Springer International Publishing, pp. 279-287.

Hajli, N., Shanmugam, M., Powell, P. and Love, P.E.D. (2015). "A Study on the Continuance Participation in On-Line Communities with Social Commerce Perspective," Technological Forecasting and Social Change, 96, pp. 232-241.

Hajli, N. and Sims, J. (2015). "Social Commerce: The Transfer of Power from Sellers to Buyers," Technological Forecasting and Social Change, 94, pp. 350-358.

Hedges, L.V. and Olkin, I. (1980). "VoteCounting Methods in Research Synthesis," Psychological Bulletin, 88(2), pp. 359-369.

Hennig-Thurau, T., Gwinner, K.P. and Gremler, D.D. (2002). "Understanding Relationship Marketing Outcomes an Integration of Relational Benefits and Relationship Quality," Journal of Service Research, 4(3), pp. 230-247.

Horng, S.-M., Wu, C.-L. and Liang, T.-P. (2016). "How Behaviors on Social Network Sites and Online Social Capital Influence Social Commerce: The Case of Facebook," Proceedings of the 20th Pacific Asia Conference on Information Systems (PACIS).

Hsiao, K.L., Chuan-Chuan Lin, J., Wang, X.Y., Lu, H.P. and Yu, H. (2010). "Antecedents and Consequences of Trust in Online Product 
Recommendations," Online Information Review, 34(6), pp. 935953.

Hu, X., Huang, Q., Zhong, X., Davison, R.M. and Zhao, D. (2016). "The Influence of Peer Characteristics and Technical Features of a Social Shopping Website on a Consumer's Purchase Intention," International Journal of Information Management, 36(6, Part B), pp. 1218-1230.

Huang, L.-T. (2016). "Flow and Social Capital Theory in Online Impulse Buying," Journal of Business Research, 69(6), pp. 2277-2283.

Huang, Z. and Benyoucef, M. (2013). "From E-Commerce to Social Commerce: A Close Look at Design Features," Electronic Commerce Research and Applications, 12(4), pp. 246-259.

Hudson, S., Roth, M.S., Madden, T.J. and Hudson, R. (2015). "The Effects of Social Media on Emotions, Brand Relationship Quality, and Word of Mouth: An Empirical Study of Music Festival Attendees," Tourism Management, 47, pp. 68-76.

Hwang, I.J., Lee, B.G. and Kim, K.Y. (2014). "Information Asymmetry, Social Networking Site Word of Mouth, and Mobility Effects on Social Commerce in Korea," Cyberpsychology Behavior and Social Networking, 17(2), pp. 117-124.

Ickler, H., Schülke, S., Wilfling, S. and Baumöl, U. (2009). "New Challenges in E-Commerce: How Social Commerce Influences the Customer Process," Proceedings of the 5th National Conference on Computing and Information Technology (NCCIT), pp. 51-57.

Jang, H., Ko, I. and Kim, J. (2013). "The Effect of Group-Buy Social Commerce and Coupon on Satisfaction and Continuance Intention - Focusing on the Expectation Confirmation Model
(ECM)," Proceedings of the 46th Hawaii International Conference on System Sciences (HICSS), pp. 29382948.

Kang, J.-Y.M. and Johnson, K.K.P. (2013). "How Does Social Commerce Work for Apparel Shopping? Apparel Social E-Shopping with Social Network Storefronts," Journal of Customer Behaviour, 12(1), pp. 53-72.

Kang, J.-Y.M. and Johnson, K.K.P. (2015). "F-Commerce Platform for Apparel Online Social Shopping: Testing a Mowen's 3M Model," International Journal of Information Management, 35(6), pp. 691-701.

Kim, J.B. (2015). "The Mediating Role of Presence on Consumer Intention to Participate in a Social Commerce Site," Journal of Internet Commerce, 14(4), pp. 425-454.

Kim, S.-B., Sun, K.-A. and Kim, D.-Y. (2013a). "The Influence of Consumer Value-Based Factors on AttitudeBehavioral Intention in Social Commerce: The Differences between High- and Low-Technology Experience Groups," Journal of Travel \& Tourism Marketing, 30(1/2), pp. 108-125.

Kim, S. and Park, H. (2013). "Effects of Various Characteristics of Social Commerce (S-Commerce) on Consumers' Trust and Trust Performance," International Journal of Information Management, 33(2), pp. 318-332.

Kim, Y., Lim, K. and Jung, N. (2013b). "A Social Commerce Customers' Price Fairness Perception Affects Their Repurchase Intention," Proceedings of the 15th International Conference on Advanced Communication Technology (ICACT), pp. 1042-1048.

King, W.R. and He, J. (2005). "Understanding the Role and Methods of Meta-Analysis in Is Research," 
Communications of the Association for Information Systems, 16(1), pp. 665-686.

Koufaris, M. (2002). "Applying the Technology Acceptance Model and Flow Theory to Online Consumer Behavior," Information Systems Research, 13(2), pp. 205-223.

Kwahk, K.-Y. and Ge, X. (2012). "The Effects of Social Media on ECommerce: A Perspective of Social Impact Theory," Proceedings of the 45th Hawaii International Conference on System Sciences (HICSS), R.H. Sprague (ed.): IEEE, pp. 1814-1823.

Lakey, B. and Cohen, S. (2000). "Social Support Theory and Measurement," in S. Cohen, L.G. Underwood and B.H. Gottlieb (eds.), Measuring and Intervening in Social Support. New York, USA: Oxford University Press, pp. 29-52.

Lee, J., Cha, M.S. and Cho, C. (2012). "Online Service Quality in Social Commerce Websites," in V. Khachidze, T. Wang, S. Siddiqui, V. Liu, S. Cappuccio and A. Lim (eds.), Contemporary Research on EBusiness Technology and Strategy. Heidelberg, Germany: Springer, pp. 335-351.

Leitner, P. and Grechenig, T. (2007a). "Community Driven Commerce: Design of an Integrated Framework for Social Shopping," Proceedings of the International Conference ECommerce (IADIS), pp. 1-4.

Leitner, P. and Grechenig, T. (2007b). "Next Generation Shopping: Case Study Research on Future E-Commerce Models," Proceedings of the International Conference ECommerce (IADIS), pp. 312-316.

Li, H., Yao, Z. and Bai, Y. (2014). "Social Commerce User Purchase Intention Study: What Factors Are Taking Effect?," Proceedings of the 18th
Pacific Asia Conference on Information Systems (PACIS).

Liang, T.-P., Ho, Y.-T., Li, Y.-W. and Turban, E. (2011). "What Drives Social Commerce: The Role of Social Support and Relationship Quality," International Journal of Electronic Commerce, 16(2), pp. 69-90.

Liang, T.-P. and Turban, E. (2011). "Introduction to the Special Issue Social Commerce: A Research Framework for Social Commerce," International Journal of Electronic Commerce, 16(2), pp. 5-14.

Light, R.J. and Smith, P.V. (1971). "Accumulating Evidence: Procedures for Resolving Contradictions among Different Research Studies," Harvard Educational Review, 41(4), pp. 429471.

Liu, H., Chu, H., Huang, Q. and Chen, X. (2016a). "Enhancing the Flow Experience of Consumers in China through Interpersonal Interaction in Social Commerce," Computers in Human Behavior, 58, pp. 306-314.

Liu, I.L.B., Cheung, C.M.K. and Lee, M.K.O. (2013). "Customer Information Sharing Behavior in Social Shopping Communities: A Social Capital Perspective," Proceedings of the 17th Pacific Asia Conference on Information Systems (PACIS).

Liu, L., Cheung, C.M.K. and Lee, M.K.O. (2016b). "An Empirical Investigation of Information Sharing Behavior on Social Commerce Sites," International Journal of Information Management, 36(5), pp. 686-699.

Liu, L., Yin, C. and Yang, J. (2014). "Understanding User Intention to Share Information in Online Social Shopping Communities: The Moderating Effect of Community Equity," Proceedings of the 18th Pacific Asia Conference on Information Systems (PACIS). 
Lu, B., Fan, W. and Zhou, M. (2016). "Social Presence, Trust, and Social Commerce Purchase Intention: An Empirical Research," Computers in Human Behavior, 56, pp. 225-237.

Luhmann, N. (1979). Trust and Power. Chichester, United Kingdom: Wiley.

McKnight, D.H., Choudhury, V. and Kacmar, C. (2002). "Developing and Validating Trust Measures for e-Commerce: An Integrative Typology," Information Systems Research, 13(3), pp. 334359.

Morgan, R.M. and Shelby, D.H. (1994). "The Commitment-Trust Theory of Relationship Marketing," Journal of Marketing, 58(3), pp. 20-38.

Ng, C.S.-P. (2013). "Intention to Purchase on Social Commerce Websites across Cultures: A Cross-Regional Study," Information \& Management, 50(8), pp. 609-620.

Noh, M., Lee, K., Kim, S. and Garrison, G. (2013). "Effects of Collectivism on Actual S-Commerce Use and the Moderating Effect of Price Consciousness," Journal of Electronic Commerce Research, 14(3), pp. 244260.

Olbrich, R. and Holsing, C. (2011). "Modeling Consumer Purchasing Behavior in Social Shopping Communities with Clickstream Data," International Journal of Electronic Commerce, 16(2), pp. 15-40.

Park, M.-S., Shin, J.-K. and Ju, Y. (2014). "The Effect of Online Social Network Characteristics on Consumer Purchasing Intention of Social Deals," Global Economic Review, 43(1), pp. 25-41.

Pavlou, P.A. (2003). "Consumer Acceptance of Electronic Commerce: Integrating Trust and Risk with the Technology Acceptance Model," International Journal of Electronic Commerce, 7(3), pp. 101-134.
Pavlou, P.A. and Fygenson, M. (2006). "Understanding and Predicting Electronic Commerce Adoption: An Extension of the Theory of Planned Behavior," MIS Quarterly, pp. 115-143.

Pavlou, P.A., Liang, H. and Xue, Y. (2007). "Understanding and Mitigating Uncertainty in Online Exchange Relationships: A Principal-Agent Perspective," MIS Quarterly, 31(1), pp. 105-136.

Pöyry, E., Parvinen, P. and Malmivaara, T. (2013). "Can We Get from Liking to Buying? Behavioral Differences in Hedonic and Utilitarian Facebook Usage," Electronic Commerce Research and Applications, 12(4), pp. 224-235.

Qin, L. and Kong, S. (2015). "Perceived Helpfulness, Perceived Trustworthiness, and Their Impact upon Social Commerce Users' Intention to Seek Shopping Recommendations," Journal of Internet Commerce, 14(4), pp. 492508.

Rad, A.A. and Benyoucef, M. (2010). "A Model for Understanding Social Commerce," Proceedings of the 3rd Annual Conference on Information Systems Applied Research, pp. 1-11.

Rivis, A. and Sheeran, P. (2003). "Social Influences and the Theory of Planned Behaviour: Evidence for a Direct Relationship Between Prototypes and Young People's Exercise Behaviour," Psychology \& Health, 18(5), pp. 567583.

Ruan, Y., Li, Q. and Xu, X. (2016). "What Makes Social Shopping?: ReExamining the Effects of MultiAttributes Utility, Trust and Relationship on Social Shopping Intention," Proceedings of the 18th Annual International Conference on Electronic Commerce: ACM, pp. 1-8. 
Saundage, D. and Lee, C.Y. (2011). "Social Commerce Activities - a Taxonomy," Proceedings of the Australiasian Conference on Information Systems (ACIS), P. Seltsikas, D. Bunker, L. Dawson and M. Indulska (eds.), pp. 19.

Sharma, S. and Crossler, R.E. (2014a). "Disclosing Too Much? Situational Factors Affecting Information Disclosure in Social Commerce Environment," Electronic Commerce Research and Applications, 13(5), pp. 305-319.

Sharma, S. and Crossler, R.E. (2014b). "Intention to Engage in Social Commerce: Uses and Gratifications Approach," Proceedings of the 20th Americas Conference on Information Systems (AMCIS), pp. 1-12.

Shen, J. (2012a). "Social Comparison, Social Presence, and Enjoyment in the Acceptance of Social Shopping Websites," Journal of Electronic Commerce Research, 13(3), pp. 198212.

Shen, J. (2012b). "Understanding User's Acceptance of Social Shopping Websites: Effects of Social Comparison and Trust," in R. Zhang, J. Zhang, Z. Zhang, J. Filipe and J. Cordeiro (eds.), Enterprise Information Systems. Heidelberg, Germany: Springer, pp. 365-373.

Shi, S. and Chow, W.S. (2015). "Trust Development and Transfer in Social Commerce: Prior Experience as Moderator," Industrial Management \& Data Systems, 115(7), pp. 1182-1203.

Shin, D.-H. (2013). "User Experience in Social Commerce: In Friends We Trust," Behaviour \& Information Technology, 32(1), pp. 52-67.

Short, J., Williams, E. and Christie, B. (1976). The Social Psychology of Telecommunications. London, United Kingdom: Wiley.
Song, H.G., Chung, N. and Koo, C. (2015). "Impulsive Buying Behavior of Restaurant Products in Social Commerce: A Role of Serendipity and Scarcity Message," Proceedings of the 19th Pacific Asia Conference on Information Systems (PACIS).

Stephen, A.T. and Toubia, O. (2010). "Deriving Value from Social Commerce Networks," Journal of Marketing Research, 47(2), pp. 215228.

Sun, Y., Wei, K.K., Fan, C.B., Lu, Y.B. and Gupta, S. (2016). "Does Social Climate Matter? On Friendship Groups in Social Commerce," Electronic Commerce Research and Applications, 18, pp. 37-47.

Teh, P.-L. and Ahmed, P.K. (2011). "MOA and TRA in Social Commerce: An Integrated Model," Proceedings of the IEEE International Conference on Industrial Engineering and Engineering Management (IEEM), pp. 1375-1379.

Teh, P.-L. and Ahmed, P.K. (2012). "Understanding Social Commerce Adoption: An Extension of the Technology Acceptance Model," Proceedings of the International Conference on Management of Innovation and Technology (ICMIT): IEEE, pp. 359-364.

Turban, E., Bolloju, N. and Liang, T.-P. (2010). "Social Commerce: An ECommerce Perspective," Proceedings of the 12th International Conference on Electronic Commerce (ICEC), T. Bui (ed.): ACM, pp. 33-42.

Venkatesh, V., Morris, M.G., Gordon, B.D. and Davis, F.D. (2003). "User Acceptance of Information Technology: Toward a Unified View," MIS Quarterly, 27(3), pp. 425-478.

Wang, C. and Zhang, P. (2012). "The Evolution of Social Commerce: The People, Management, Technology, 
and Information Dimensions," Communications of the Association for Information Systems, 31(5), pp. 105-127.

Wang, Y. and Hajli, M. (2014). "Co-Creation in Branding through Social Commerce: The Role of Social Support, Relationship Quality and Privacy Concerns," Proceedings of the 20th Americas Conference on Information Systems (AMCIS), pp. 1-16.

Wang, Y. and Yu, C. (2015). "Social Interaction-Based Consumer Decision-Making Model in Social Commerce: The Role of Word of Mouth and Observational Learning," International Journal of Information Management.

Webster, J. and Watson, R.T. (2002). "Analyzing the Past to Prepare for the Future: Writing a Literature Review," MIS Quarterly, 26(2), pp. xiii-xxiii.

Xi, H., Hong, Z., Jianshan, S., Li, X., Jiuchang, W. and Davison, R. (2016). "Impulsive Purchase Behaviour in Social Commerce: The Role of Social Influence," Proceedings of the 20th Pacific Asia Conference on Information Systems (PACIS).

Xiang, L., Zheng, X.B., Lee, M.K.O. and Zhao, D.T. (2016). "Exploring Consumers' Impulse Buying Behavior on Social Commerce Platform: The Role of Parasocial Interaction," International Journal of Information Management, 36(3), pp. 333-347.
Zeithaml, V.A. (1988). "Consumer Perceptions of Price, Quality, and Value: A Means-End Model and Synthesis of Evidence," Journal of Marketing, 52(3), pp. 2-22.

Zhang, H., Lu, Y., Gupta, S. and Zhao, L. (2014). "What Motivates Customers to Participate in Social Commerce? The Impact of Technological Environments and Virtual Customer Experiences," Information \& Management, 51(8), pp. 1017-1030.

Zhang, K.Z.K. and Benyoucef, M. (2016). "Consumer Behavior in Social Commerce: A Literature Review," Decision Support Systems, 86, pp. 95-108.

Zhang, K.Z.K., Benyoucef, M. and Zhao, S.J. (2015). "Consumer Participation and Gender Differences on Companies' Microblogs: A Brand Attachment Process Perspective," Computers in Human Behavior, 44, pp. 357-368.

Zhang, K.Z.K., Benyoucef, M. and Zhao, S.J. (2016). "Building Brand Loyalty in Social Commerce: The Case of Brand Microblogs," Electronic Commerce Research and Applications, 15, pp. 14-25.

Zhou, L., Zhang, P. and Zimmermann, H.-D. (2013). "Social Commerce Research: An Integrated View," Electronic Commerce Research and Applications, 12(2), pp. 61-68. 


\section{Appendix A: Detailed Results of Literature Review}

\begin{tabular}{|c|c|c|c|}
\hline \multirow{2}{*}{ Constructs } & \multicolumn{2}{|c|}{ Impact } & \multirow{2}{*}{ Study } \\
\hline & 0 & + & \\
\hline \multicolumn{4}{|l|}{ Trust $(n=20)$} \\
\hline \multicolumn{4}{|c|}{ Outcome variable: Use intention/behavior } \\
\hline Trust & \begin{tabular}{l|l} 
& n.s.
\end{tabular} & & (Shen, 2012b) \\
\hline Trust & & $+t^{* * *}$ & (Teh and Ahmed, 2012) \\
\hline Trust & & $+t^{* \star *}$ & (Zhang et al., 2015) \\
\hline Perceived trust & & $+^{* *}$ & (Shin, 2013) \\
\hline Trust towards community & & $+t^{* * *}$ & (Chen and Shen, 2015) \\
\hline Trust towards members & & $+t^{* * *}$ & (Chen and Shen, 2015) \\
\hline Perceived trustworthiness of SNSs & & $+t^{* * *}$ & (Kang and Johnson, 2013) \\
\hline Trust in vendor & & $+^{*}$ & (Ruan et al., 2016) \\
\hline Trust towards website & & $+^{*}$ & (Farivar et al., 2016) \\
\hline Trust towards members & \begin{tabular}{l|r} 
& n.s. \\
\end{tabular} & & (Farivar et al., 2016) \\
\hline \multicolumn{4}{|c|}{ Outcome variable: Purchase intention/behavior } \\
\hline Trust & & $+^{*}$ & (Hajli, 2012) \\
\hline Trust & & $+^{*}$ & (Hajli, 2014a) \\
\hline Trust & & $+t^{* * *}$ & (Hajli, 2015) \\
\hline Trust & & $+^{*}$ & (Hajli and Lin, 2015) \\
\hline Trust & & $+t^{* *}$ & (Kim and Park, 2013) \\
\hline Trust towards members & n.s. & & (Farivar et al., 2016) \\
\hline Trust towards website & & $+t^{* *}$ & (Farivar et al., 2016) \\
\hline Trust in website & & $+t^{* *}$ & (Hsiao et al., 2010) \\
\hline Trust in product recommendation & & $+t^{* * *}$ & (Hsiao et al., 2010) \\
\hline Trust in sellers & & $+^{* *}$ & (Lu et al., 2016) \\
\hline Trust in social network community & & $+t^{\star * *}$ & $(\mathrm{Ng}, 2013)$ \\
\hline \multicolumn{4}{|c|}{ Outcome variable: Continuance intention/behavior } \\
\hline Trust & & $++^{*}$ & (Gamboa and Gonçalves, 2014) \\
\hline Trust & & $+^{*}$ & (Gamboa and Gonçalves, 2014) \\
\hline \multicolumn{4}{|c|}{ Outcome variable: Information sharing intention/behavior } \\
\hline Trust & & $++^{\star *}$ & (Kim and Park, 2013) \\
\hline Trust & & $+t^{* * *}$ & (Liu et al., 2013) \\
\hline Trust towards community & & $++^{* \star *}$ & (Chen and Shen, 2015) \\
\hline Trust towards members & n.s. & & (Chen and Shen, 2015) \\
\hline Company trust & & $+t^{* *}$ & (Shi and Chow, 2015) \\
\hline Information-based trust & n.s. & & (Shi and Chow, 2015) \\
\hline Identification-based trust & & $+t^{\star *}$ & (Shi and Chow, 2015) \\
\hline \multicolumn{4}{|c|}{ Outcome variable: Information seeking intention/behavior } \\
\hline $\begin{array}{l}\text { Perceived trustworthiness of social } \\
\text { commerce site }\end{array}$ & & $+t^{* *}$ & (Qin and Kong, 2015) \\
\hline $\begin{array}{l}\text { Perceived trustworthiness of other users' } \\
\text { competence }\end{array}$ & n.s. & & (Qin and Kong, 2015) \\
\hline \multicolumn{4}{|l|}{ Usefulness $(n=13)$} \\
\hline \multicolumn{4}{|c|}{ Outcome variable: Use intention/behavior } \\
\hline Usefulness & & $++^{* *}$ & $(\mathrm{Kim}, 2015)$ \\
\hline Perceived usefulness & & $+t^{* * *}$ & (Featherman and Hajli, 2015) \\
\hline Perceived usefulness & & $+{ }^{* *}$ & (Noh et al., 2013) \\
\hline Perceived usefulness & & $+* * *$ & (Shen, 2012a) \\
\hline Perceived usefulness & & $+t^{\star \star *}$ & (Shen, 2012b) \\
\hline Perceived usefulness & & $++^{* *}$ & (Shin, 2013) \\
\hline
\end{tabular}


Friedrich: On the Factors Influencing Consumers' Adoption of Social Commerce

On the Factors Influencing Consumers' Adoption of Social Commerce / Friedrich

\begin{tabular}{|c|c|c|c|}
\hline Perceived usefulness & n.s. & & (Teh and Ahmed, 2012) \\
\hline Performance expectancy & & $+^{*}$ & (Gatautis and Medziausiene, 2014) \\
\hline \multicolumn{4}{|c|}{ Outcome variable: Purchase intention/behavior } \\
\hline Perceived usefulness & & $+^{*}$ & (Hajli, 2012) \\
\hline Perceived usefulness & & $+t^{* *}$ & (Hajli, 2014a) \\
\hline Perceived usefulness & & $+^{*}$ & (Hajli and Lin, 2015) \\
\hline \multicolumn{4}{|c|}{ Outcome variable: Information sharing intention/behavior } \\
\hline Perceived usefulness & \begin{tabular}{l|l} 
& n.s. \\
\end{tabular} & & (Chen et al., 2014) \\
\hline \multicolumn{4}{|c|}{ Outcome variable: Information disclosure intention/behavior } \\
\hline Perceived usefulness & & $+t^{* * *}$ & (Sharma and Crossler, 2014a) \\
\hline \multicolumn{4}{|l|}{ Enjoyment $(n=11)$} \\
\hline \multicolumn{4}{|c|}{ Outcome variable: Use intention/behavior } \\
\hline Enjoyment & & $++^{* *}$ & $(\mathrm{Kim}, 2015)$ \\
\hline Perceived enjoyment & n.s. & & (Sharma and Crossler, 2014b) \\
\hline Perceived enjoyment & & $+t^{* *}$ & (Shen, 2012a) \\
\hline Perceived enjoyment & & $+^{*}$ & (Shin, 2013) \\
\hline Flow & & $++^{*}$ & (Zhang et al., 2014) \\
\hline Flow & & $+^{*}$ & (Zhang et al., 2014) \\
\hline \multicolumn{4}{|c|}{ Outcome variable: Purchase intention/behavior } \\
\hline Perceived enjoyment & \begin{tabular}{l|l} 
& n.s. \\
\end{tabular} & & (Song et al., 2015) \\
\hline Perceived enjoyment & & $+^{*}$ & (Xiang et al., 2016) \\
\hline Flow experience & & $+t^{* * *}$ & (Liu et al., 2016a) \\
\hline \multicolumn{4}{|c|}{ Outcome variable: Information sharing intention/behavior } \\
\hline Enjoyment of helping & \begin{tabular}{l|l} 
& n.s. \\
\end{tabular} & & (Liu et al., 2016b) \\
\hline Enjoyment in helping others & & $+t^{* * *}$ & (Liu et al., 2014) \\
\hline \multicolumn{4}{|c|}{ Outcome variable: Information disclosure intention/behavior } \\
\hline Perceived enjoyment & & $++^{* *}$ & (Sharma and Crossler, 2014a) \\
\hline \multicolumn{4}{|l|}{ Social influence $(n=8)$} \\
\hline \multicolumn{4}{|c|}{ Outcome variable: Use intention/behavior } \\
\hline Social influence & & $++^{\star *}$ & (Gatautis and Medziausiene, 2014) \\
\hline Subjective norm & & $+t^{* * *}$ & (Featherman and Hajli, 2015) \\
\hline Subjective norm & & $+t^{* * *}$ & (Sharma and Crossler, 2014b) \\
\hline Subjective norm & & $+t^{* *}$ & (Shin, 2013) \\
\hline Normative social influence & & $+t^{* *}$ & (Kwahk and Ge, 2012) \\
\hline Informational social influence & & $+t^{* *}$ & (Kwahk and Ge, 2012) \\
\hline Normative belief & & $++^{\star \star \star}$ & (Teh and Ahmed, 2011) \\
\hline \multicolumn{4}{|c|}{ Outcome variable: Purchase intention/behavior } \\
\hline Normative social influence & \begin{tabular}{l|l|}
$-* *$ & \\
\end{tabular} & & (Kwahk and Ge, 2012) \\
\hline Informational social influence & & $+t^{* *}$ & (Kwahk and $\mathrm{Ge}, 2012$ ) \\
\hline Normative social influence & & $++^{* *}$ & (Xi et al., 2016) \\
\hline Informational social influence & & $+^{*}$ & (Xi et al., 2016) \\
\hline \multicolumn{4}{|c|}{ Outcome variable: Continuance intention/behavior } \\
\hline Subjective norms & & $+t^{\star * *}$ & (Hajli et al., 2015) \\
\hline \multicolumn{4}{|l|}{ Social support $(n=8)$} \\
\hline \multicolumn{4}{|c|}{ Outcome variable: Use intention/behavior } \\
\hline Social support & & $++^{* *}$ & (Hajli, 2014b) \\
\hline Social support & & $++^{*}$ & (Hajli and Sims, 2015) \\
\hline Social support & & $+t^{* * *}$ & (Liang et al., 2011) \\
\hline Social support & & $+t^{\star \star *}$ & (Zhang et al., 2014) \\
\hline Social support & & $+t^{* * *}$ & (Zhang et al., 2014) \\
\hline Perceived social support & & $+{ }^{* *}$ & (Shin, 2013) \\
\hline \multicolumn{4}{|c|}{ Outcome variable: Purchase intention/behavior } \\
\hline Social support & & $++^{\star \star \star}$ & (Bai et al., 2015) \\
\hline
\end{tabular}


Pacific Asia Journal of the Association for Information Systems, Vol. 8, Iss. 4 [2017], Art. 2

On the Factors Influencing Consumers' Adoption of Social Commerce / Friedrich

\begin{tabular}{|c|c|c|c|c|}
\hline Social support & & & $++^{*}$ & (Li et al., 2014) \\
\hline \multicolumn{5}{|c|}{ Outcome variable: Continuance intention/behavior } \\
\hline Social support & & & $++^{\star *}$ & (Hajli et al., 2015) \\
\hline Social support & & & $++^{* *}$ & (Liang et al., 2011) \\
\hline \multicolumn{5}{|l|}{ Value $(n=8)$} \\
\hline \multicolumn{5}{|c|}{ Outcome variable: Use intention/behavior } \\
\hline Hedonic value & & & $+^{*}$ & (Kim et al., 2013a) \\
\hline Social value & & & $+^{*}$ & (Kim et al., 2013a) \\
\hline Utilitarian value & & n.s. & & (Kim et al., 2013a) \\
\hline Product utilitarian value & & & $+* * *$ & (Ruan et al., 2016) \\
\hline Shopping hedonic value & & & $+t^{\star *}$ & (Ruan et al., 2016) \\
\hline \multicolumn{5}{|c|}{ Outcome variable: Purchase intention/behavior } \\
\hline Perceived value & & & $+t^{\star * *}$ & (Cho et al., 2012) \\
\hline Perceived utilitarian value & & & $+t^{\star *}$ & (Hu et al., 2016) \\
\hline Perceived social value & & & $++^{* *}$ & (Hu et al., 2016) \\
\hline Hedonic value & & & $+^{*}$ & (Sun et al., 2016) \\
\hline Social value & & & $+t^{* *}$ & (Sun et al., 2016) \\
\hline Self-discovery value & & & $+t^{\star \star *}$ & (Sun et al., 2016) \\
\hline Informational value & & n.s. & & (Sun et al., 2016) \\
\hline \multicolumn{5}{|c|}{ Outcome variable: Continuance intention/behavior } \\
\hline Perceived value & & & $+t^{\star \star *}$ & (Hajli et al., 2015) \\
\hline Perceived value & & & $+t^{* * *}$ & (Lee et al., 2012) \\
\hline Perceived value & & & $+^{*}$ & (Gamboa and Gonçalves, 2014) \\
\hline Perceived value & & n.s. & & (Gamboa and Gonçalves, 2014) \\
\hline \multicolumn{5}{|l|}{ Ease of use $(n=5)$} \\
\hline \multicolumn{5}{|c|}{ Outcome variable: Use intention/behavior } \\
\hline Perceived ease of use & & & $+t^{\star \star \star}$ & (Featherman and Hajli, 2015) \\
\hline Perceived ease of use & & & $+t^{* *}$ & (Noh et al., 2013) \\
\hline Perceived ease of use & & n.s. & & (Teh and Ahmed, 2012) \\
\hline Effort expectancy & & & $+t^{\star *}$ & (Gatautis and Medziausiene, 2014) \\
\hline \multicolumn{5}{|c|}{ Outcome variable: Purchase intention/behavior } \\
\hline Perceived ease of use & & & $+^{*}$ & (Hajli and Lin, 2015) \\
\hline \multicolumn{5}{|c|}{ Relationship quality $(n=5)$} \\
\hline \multicolumn{5}{|c|}{ Outcome variable: Use intention/behavior } \\
\hline Relationship quality & & & $+t^{\star *}$ & (Hajli, 2014b) \\
\hline Relationship quality & & & $+^{*}$ & (Liang et al., 2011) \\
\hline Relationship quality & & & $+t^{\star \star *}$ & (Wang and Hajli, 2014) \\
\hline \multicolumn{5}{|c|}{ Outcome variable: Continuance intention/behavior } \\
\hline Relationship quality & & & $+t^{\star \star \star}$ & (Liang et al., 2011) \\
\hline Relationship quality & & & $+t^{\star \star \star}$ & (Zhang et al., 2016) \\
\hline \multicolumn{5}{|c|}{ Outcome variable: Information sharing intention/behavior } \\
\hline Brand relationship quality & & & $+t^{\star * *}$ & (Hudson et al., 2015) \\
\hline \multicolumn{5}{|l|}{ Attitude $(n=4)$} \\
\hline \multicolumn{5}{|c|}{ Outcome variable: Use intention/behavior } \\
\hline Attitude & & & $+* * *$ & (Kim et al., 2013a) \\
\hline Attitude & & & $++^{\star *}$ & (Shin, 2013) \\
\hline Attitude towards s-commerce & & n.s. & & (Teh and Ahmed, 2011) \\
\hline \multicolumn{5}{|c|}{ Outcome variable: Continuance intention/behavior } \\
\hline Attitude & & & $+t^{\star \star \star}$ & (Hajli et al., 2015) \\
\hline \multicolumn{5}{|l|}{ Risk (n = 4) } \\
\hline \multicolumn{5}{|c|}{ Outcome variable: Use intention/behavior } \\
\hline Assessed usage risk & $-{ }^{* *}$ & & & (Featherman and Hajli, 2015) \\
\hline Perceived risk & & n.s. & & (Ruan et al., 2016) \\
\hline
\end{tabular}

28 Pacific Asia Journal of the Association for Information Systems Vol. 8 No. 4, pp.1-32 / December 2016 https://aisel.aisnet.org/pajais/vol8/iss4/2 


\begin{tabular}{|c|c|c|c|c|}
\hline Perceived participation risk & $--^{* * *}$ & & & (Farivar et al., 2016) \\
\hline \multicolumn{5}{|c|}{ Outcome variable: Purchase intention/behavior } \\
\hline Perceived commerce risk & $--^{* \star *}$ & & & (Farivar et al., 2016) \\
\hline \multicolumn{5}{|c|}{ Outcome variable: Information disclosure intention/behavior } \\
\hline Perceived privacy risk & $-* * *$ & & & (Sharma and Crossler, 2014a) \\
\hline \multicolumn{5}{|l|}{ Commitment $(n=3)$} \\
\hline \multicolumn{5}{|c|}{ Outcome variable: Use intention/behavior } \\
\hline Commitment & & & $+t^{\star * *}$ & (Zhang et al., 2015) \\
\hline Community commitment & & & $++^{*}$ & (Chen and Shen, 2015) \\
\hline \multicolumn{5}{|c|}{ Outcome variable: Continuance intention/behavior } \\
\hline Commitment & & & $+^{*}$ & (Gamboa and Gonçalves, 2014) \\
\hline Commitment & & & $++^{*}$ & (Gamboa and Gonçalves, 2014) \\
\hline \multicolumn{5}{|c|}{ Social commerce constructs $(n=3)$} \\
\hline \multicolumn{5}{|c|}{ Outcome variable: Use intention/behavior } \\
\hline Social commerce constructs & & & $++^{\star * *}$ & (Hajli and Sims, 2015) \\
\hline Social commerce constructs & & & $++^{\star *}$ & (Wang and Hajli, 2014) \\
\hline \multicolumn{5}{|c|}{ Outcome variable: Purchase intention/behavior } \\
\hline Social commerce constructs & & & $+t^{\star * *}$ & (Hajli, 2015) \\
\hline \multicolumn{5}{|l|}{ Familiarity $(n=2)$} \\
\hline \multicolumn{5}{|c|}{ Outcome variable: Use intention/behavior } \\
\hline Familiarity & & & $+t^{\star * *}$ & (Sharma and Crossler, 2014b) \\
\hline \multicolumn{5}{|c|}{ Outcome variable: Purchase intention/behavior } \\
\hline Familiarity & & n.s. & & $(\mathrm{Ng}, 2013)$ \\
\hline \multicolumn{5}{|l|}{ Satisfaction $(n=2)$} \\
\hline \multicolumn{5}{|c|}{ Outcome variable: Continuance intention/behavior } \\
\hline Customer satisfaction & & & $++^{*}$ & (Gamboa and Gonçalves, 2014) \\
\hline Customer satisfaction & & & $++^{*}$ & (Gamboa and Gonçalves, 2014) \\
\hline Site satisfaction & & & $++^{* *}$ & (Jang et al., 2013) \\
\hline Coupon satisfaction & & & $++^{* *}$ & (Jang et al., 2013) \\
\hline \multicolumn{5}{|l|}{ Social presence $(n=2)$} \\
\hline \multicolumn{5}{|c|}{ Outcome variable: Use intention/behavior } \\
\hline Social presence & & n.s. & & (Sharma and Crossler, 2014b) \\
\hline Social presence & & n.s. & & (Zhang et al., 2014) \\
\hline Social presence & & & $+t^{* *}$ & (Zhang et al., 2014) \\
\hline \multicolumn{5}{|l|}{ Uncertainty $(n=2)$} \\
\hline \multicolumn{5}{|c|}{ Outcome variable: Purchase intention/behavior } \\
\hline Uncertainty & $--^{* * *}$ & & & (Hwang et al., 2014) \\
\hline Product uncertainty & $-{ }^{*}$ & & & (Bai et al., 2015) \\
\hline Seller uncertainty & $-{ }^{* *}$ & & & (Bai et al., 2015) \\
\hline \multicolumn{5}{|l|}{ Others $(n=1)$} \\
\hline \multicolumn{5}{|c|}{ Outcome variable: Use intention/behavior } \\
\hline Ability & & & $+^{*}$ & (Teh and Ahmed, 2011) \\
\hline Conformity motivation & & & $+t^{* * *}$ & (Kang and Johnson, 2013) \\
\hline Consumer self-confidence & & n.s. & & (Kang and Johnson, 2013) \\
\hline Cool \& new trend & & & $+t^{* * *}$ & (Sharma and Crossler, 2014b) \\
\hline Facilitating conditions & & & $+^{*}$ & (Gatautis and Medziausiene, 2014) \\
\hline Information quality & & & $+t^{* * *}$ & (Sharma and Crossler, 2014b) \\
\hline Information-seeking gratification & & & $+{ }^{* \star *}$ & (Kang and Johnson, 2015) \\
\hline Market mavenism & & & $+t^{* * *}$ & (Kang and Johnson, 2015) \\
\hline Motivation & & & $+t^{* *}$ & (Teh and Ahmed, 2011) \\
\hline Online bonding social capital & & & $+t^{* * *}$ & (Horng et al., 2016) \\
\hline Online bridging social capital & & & $+t^{\star \star \star}$ & (Horng et al., 2016) \\
\hline
\end{tabular}


Pacific Asia Journal of the Association for Information Systems, Vol. 8, Iss. 4 [2017], Art. 2

On the Factors Influencing Consumers' Adoption of Social Commerce / Friedrich

\begin{tabular}{|c|c|c|c|c|}
\hline Opinion seeking in SNSs & & & $++^{* * *}$ & (Kang and Johnson, 2013) \\
\hline Opportunity & & n.s. & & (Teh and Ahmed, 2011) \\
\hline Perceived participation benefit & & & $++^{\star \star *}$ & (Farivar et al., 2016) \\
\hline Reciprocal altruism & & & $++^{* *}$ & (Ruan et al., 2016) \\
\hline Search costs & $-{ }^{*}$ & & & (Ruan et al., 2016) \\
\hline Service quality & & & $+t^{* *}$ & (Ruan et al., 2016) \\
\hline Sociability & & n.s. & & (Kang and Johnson, 2013) \\
\hline Social browsing & & & $++^{*}$ & (Kang and Johnson, 2015) \\
\hline Socializing gratification & & & $++^{\star * *}$ & (Kang and Johnson, 2015) \\
\hline Value consciousness & & & $++^{* * *}$ & (Kang and Johnson, 2015) \\
\hline Website quality & & & $t^{* * *}$ & (Liang et al., 2011) \\
\hline \multicolumn{5}{|c|}{ Outcome variable: Purchase intention/behavior } \\
\hline Affective involvement & & & $++^{* *}$ & (Park et al., 2014) \\
\hline Bargain percept & & n.s. & & (Anderson et al., 2014) \\
\hline Browsing activities & & & $+^{*}$ & (Huang, 2016) \\
\hline Closeness & & n.s. & & $(\mathrm{Ng}, 2013)$ \\
\hline Cognitive involvement & & & $+^{*}$ & (Park et al., 2014) \\
\hline Consumer knowledge & $-{ }^{*}$ & & & (Li et al., 2014) \\
\hline Discounted price & & n.s. & & (Song et al., 2015) \\
\hline Experiential shopping & & n.s. & & (Anderson et al., 2014) \\
\hline Information access & & n.s. & & (Anderson et al., 2014) \\
\hline Learning and training & & & $+^{*}$ & (Hajli and Lin, 2015) \\
\hline Negative valence WOM & $-* * *$ & & & (Wang and Yu, 2015) \\
\hline Observe consumer purchase & & & $+{ }^{*}$ & (Wang and Yu, 2015) \\
\hline Parasocial interaction & & & $++^{* * *}$ & (Xiang et al., 2016) \\
\hline Peer communication & & & $+^{*}$ & (Huang, 2016) \\
\hline Positive valence WOM & & & $+^{* *}$ & (Wang and $\mathrm{Yu}, 2015$ ) \\
\hline Scarcity & & & $+^{* *}$ & (Song et al., 2015) \\
\hline Serendipitous information & & & $+^{*}$ & (Song et al., 2015) \\
\hline Social commerce cognition & & & $+{ }^{*}$ & (Li et al., 2014) \\
\hline Time savings & & & $+^{*}$ & (Anderson et al., 2014) \\
\hline WOM content & & & $++^{\star \star \star}$ & (Wang and Yu, 2015) \\
\hline \multicolumn{5}{|c|}{ Outcome variable: Continuance intention/behavior } \\
\hline Bargain percept & & n.s. & & (Anderson et al., 2014) \\
\hline Brand experience & & & $++^{* * *}$ & (Chen et al., 2014) \\
\hline Contact & & n.s. & & (Lee et al., 2012) \\
\hline Efficiency & & & $++^{* *}$ & (Lee et al., 2012) \\
\hline Experiential shopping & & & $+^{*}$ & (Anderson et al., 2014) \\
\hline Fulfillment & & & $+t^{* \star *}$ & (Lee et al., 2012) \\
\hline Information access & & & $+^{*}$ & (Anderson et al., 2014) \\
\hline Perceived behavioral control & & & $+^{*}$ & (Hajli et al., 2015) \\
\hline Price fairness perception & & & $++^{*}$ & (Kim et al., 2013b) \\
\hline Privacy & & & $++^{* * *}$ & (Lee et al., 2012) \\
\hline Responsiveness & & & $+t^{\star \star *}$ & (Lee et al., 2012) \\
\hline Time savings & & n.s. & & (Anderson et al., 2014) \\
\hline Website quality & & & $+^{*}$ & (Liang et al., 2011) \\
\hline \multicolumn{5}{|c|}{ Outcome variable: Information sharing intention/behavior } \\
\hline Anticipated extrinsic rewards & & & $+t^{* \star *}$ & (Liu et al., 2014) \\
\hline Anticipated reciprocal relationships & & & $+^{* *}$ & (Liu et al., 2014) \\
\hline Customer expertise & & & $++^{* * *}$ & (Liu et al., 2016b) \\
\hline Emotional attachment & & & $+t^{* * *}$ & (Hudson et al., 2015) \\
\hline Identification & & n.s. & & (Liu et al., 2013) \\
\hline Indegree centrality & & & $++^{*}$ & (Liu et al., 2013) \\
\hline
\end{tabular}

30 Pacific Asia Journal of the Association for Information Systems Vol. 8 No. 4, pp.1-32 / December 2016

https://aisel.aisnet.org/pajais/vol8/iss4/2

DOI: $10.17705 / 1$ pais.08401 


\begin{tabular}{|c|c|c|c|}
\hline In-degree's feedback & & $+t^{* * *}$ & (Liu et al., 2016b) \\
\hline Knowledge self-efficacy & & $+t^{\star \star *}$ & (Liu et al., 2014) \\
\hline Outdegree centrality & & $+^{*}$ & (Liu et al. 2013) \\
\hline Out-degrees' post & & $+* * *$ & (Liu et al., 2016b) \\
\hline Peer members' postings & & $+* * *$ & (Cheung et al., 2015) \\
\hline Peer members' recommendations & & $+t^{\star \star *}$ & (Cheung et al., 2015) \\
\hline Reciprocity & & $+t^{* \star *}$ & (Liu et al., 2016b) \\
\hline Reputation & & $+^{*}$ & (Liu et al., 2016b) \\
\hline Shared language & & $+t^{\star \star *}$ & (Liu et al., 2013) \\
\hline Shared vision & & $+^{*}$ & (Liu et al., 2013) \\
\hline \multicolumn{4}{|c|}{ Outcome variable: Information seeking intention/behavior } \\
\hline Perceived helpfulness & & $+t^{\star *}$ & (Qin and Kong, 2015) \\
\hline \multicolumn{4}{|c|}{ Outcome variable: Information disclosure intention/behavior } \\
\hline Perceived ownership & n.s. & & (Sharma and Crossler, 2014a) \\
\hline Privacy apathy & & $+t^{* \star *}$ & (Sharma and Crossler, 2014a) \\
\hline
\end{tabular}

Notes: $\mathrm{n}=$ number of studies. $-=$ significant negative effect; $0=$ non-significant effect $/$ n.s. $=$ not significant; + = significant positive effect. Significance levels: ${ }^{*}=p<0.05 ;{ }^{* *}=p<0.01 ;{ }^{* * *}=p<0.001$.

\section{Appendix B: Formula of Sign Test}

$$
Z_{V C}=\frac{\left(N_{P}\right)-\left(\frac{1}{2} N\right)}{\frac{1}{2} \sqrt{N}}
$$

$Z_{\mathrm{Vc}}=\mathrm{z}$ score (i.e., standard normal deviate)

$\mathrm{N}_{\mathrm{P}}=$ number of positive findings (i.e., findings that are assumed and confirmed to be statisticallysignificant)

$\mathrm{N}=$ total number of findings (i.e., total number of significant and non-significant findings)

\section{Figure B1 - Formula of Sign Test (Cooper, 1998, p. 118)}

\section{About the Author}

Thomas Friedrich is a $\mathrm{PhD}$ candidate in Information Systems, Faculty of Information Systems and Applied Computer Sciences, at the University of Bamberg, Germany. His research interests include e-commerce (especially social commerce), enterprise resource planning, business intelligence, and business information systems modelling. 